\title{
Omnichannel Development within the Pakistani Fashion Retail
}

\author{
Syed Muhammad Abbas Rizvi ${ }^{1}$ \\ Research Scholar \\ Karachi University Business School, University of Karachi, Pakistan \\ Dr. Danish Ahmed Siddiqui \\ Associate Professor \\ Karachi University Business School, University of Karachi, Pakistan
}

\begin{abstract}
We examined the omnichannel Development within the Pakistani Fashion Retail and observed both Retailer and Consumer perspective in our study to see the development and Potential of Omnichannel. We selected 25 retailers (of which 22 are using multi-channels) and 224 shoppers who used more than one channel for purchasing fashion products, (due to some model fitness error we reduced our final sample size to 205 respondents). We used UTAUT2 model with 2 more predictors (perceived security and Personal innovativeness) which we found effected in purchase intention of consumer from some previous literature. As per Retailer Perspective we found that we are at an extremely early stage of omnichannel. Organizations are slowly transforming but some retailers are still under threat because of associated risks with changing their business models. Omnichannel loyalty service was found to be the weakest in current development due to profitability factors for organization which seem more important, and retailers also need to focus on data and analytics \& IT structure to improve omnichannel journey. As per consumer perspective, the survey results show that the security is the main concern for the shoppers in Pakistan, it restricts shopper to provide their personal information to retailers also factors of social influence and hedonic motivation not found positively influenced in our model but habit and personal innovativeness found the key factors for omnichannel development also performance and effort expectancy founds positively influenced in the development of omnichannel. By summarizing both perspective we finally conclude (Fig. 26) that retailers should integrated their all channels in a way which gives consumer totally unified and seamless shopping experience and hit their purchase intention in a positive way which support omnichannel development in Pakistan Fashion Retail Industry.
\end{abstract}

Keywords: Omnichannel, Integration, Purchase intention, transforming, loyalty services, data and analytics, Security, Effort Expectancy, Habit, Personal Innovativeness

DOI: $10.7176 / \mathrm{JMCR} / 54-06$

Publication date:March $31^{\text {st }} 2019$

\section{INTRODUCTION:}

\subsection{BACKGROUND TO THE STUDY}

Technology Revolution growingly complex the structure of the marketplace and makes more difficult to selling to consumers (Crittenden et al., 2013). The retailing business is as of now looked with the biggest change since the development of the Internet. New innovative headways and moves in client conduct are changing the manner in which customary retail has been finished. According to the article "Competing in the Age of Omnichannel Retailing" from MIT Sloan Management Review, "As technology blurs the distinctions between physical and online retailing, retailers and their supply-chain partners will need to rethink their competitive strategies" (Brynjolfsson, Hu and Rahman, 2013, p.1). The advanced shopper is associated, sagacious and has a restricted measure of consideration, which is continually competed for by a developing number of computerized contributions. To achieve the shopper a multi-channel approach, where the purchaser can get to a given offering from various channels, has empowered retailers to contend on more dimensions. Clients who have picked up an expanded measure of computerized development are currently using the accessible channels and touchpoints to scan for contributions in the most helpful way. This expects retailers to make a brought together offering over their whole directs so as to convey an intelligent ordeal for the two deals and brand acknowledgment. We are in the beginning of a revolution. Technology has changed everything, not just what we do and how - it has likewise genuinely transformed us as people and as a general public. It is an era described by the 'power of shoppers', that impact each part of business. As technology is a need for omnichannel; customers' acknowledgment and utilization of the technology sits at its center of it where a more profound comprehension of factors that drive Omni shopper conduct would be of favor.

\subsection{PROBLEM STATEMENT}

The main complexity is the Challenge of Retail for Fashion retailers, due to advancement in Technology Most

1 Corresponding Author, Textile Designer and Fashion consultant 
Pakistani retailers experiencing the tough times. Also Pakistani retailers suffer from the economic uncertainty, the retail market is saturated because of expansion and increasing numbers of competitions, retailers are more focused towards short terms benefits rather to think about gaining long term advantage to make customer loyal by providing ease in their shopping journey.

We found lots of Multi-channel retailers in Pakistan who used different strategies for different channels which affected their sales in terms of cannibalization also it confuses the customer and result in dis-satisfaction and quit to purchase from consumer side. Another complexity is to understand the customer shopping behavior for retailers and the predictors which effects and drive the purchase intention of the consumer.

\subsection{GAP ANALYSIS}

Many scholars previously research on omnichannel content, some have mainly focused on retailer's perspective (e.g. Verhoef et al., 2015; Pantano \& Viasonne, 2015; Piotrowicz \& Cuthbertson, 2014) and some highlight consumer perspective with mainly targeting in their behavioral intention as a driver for omnichannel (e.g. Accenture, 2016; Mastercard 2016; Mc Kinsey, 2016) but there is an evident gap in terms of combining the both perspective and focusing what is main drivers for the omnichannel development for retailers and what are the main predictors which influence purchase intentions of the consumer side, and how it could be give an advantage to both of them. Hence this is the first attempt in this regards. Also this study focused on finding the main indicators for the omnichannel development in Pakistan Fashion retail industry, as there were no studies done on this topic for Pakistan. Hence there is a huge gap in literature related to Pakistan highlighting omnichannel concern for fashion retail which is consider as a fastest growing industry of Pakistan.

\subsection{PURPOSE AND OBJECTIVE}

This study is to investigate how consumer would be going to shift their purchasing pattern and what are the behavior predictors which support or oppose the omnichannel development for Fashion retailer also what are the factors which retailers have to work to provide unified shopping experience for their customer to make them loyal to the brand and achieve Long-term benefit. Focused on the current development of omnichannel in Pakistani Fashion retail, this study checked the potential of retailers to acquire omnichannel retailing and its different features like Business Transformation, Organizational influence and adoption of data and analytics, it provide further brief related with clarification of omnichannel and special tools which retailer can use to improve their business and to fulfill customer need more better in terms of offering perfect omnichannel experience in future, it also evaluate the customer perspective by focusing their preferences that how likely the want to switch their shopping behavior from multi-channel to omnichannel

\subsection{SIGNIFICANCE}

Due to the advancement of technology and continuous shifting in shopper's behavior omnichannel seems as future of retail and this study is aim to provide both retailers and consumer perspective, to find out the main barriers in Omnichannel development for developing countries also the main drivers which need to be improve from retailer's side to gain an advantage of omnichannel shopping Journey. In Pakistan from the Past few years due to the boom in use of android cell phones many people are now familiar with the technology and that why now people of Pakistan are beginning to use multi channels for the purpose of shopping, due to the change in this type of dynamics there is a flourishing opportunity for the Omnichannel. Retailers like Daraz successfully getting Billion-rupees profit milestone from its Black Friday also Food panda making huge profit with huge volume of 70,000 orders in four major cities of Pakistan (Rabbani F., 2018)

Pakistan Fashion industry is at its booming stage and customers usually buy (sports clothes, shoes, accessories, fashion clothes, hand bags etc.) the Fashion related goods easily from both the channels physical and online. This is the main reason we have chosen Fashion Industry for the research of Omnichannel and its offerings.

\subsection{RESEARCH QUESTION:}

The Research Question for this proposal base on two dimension, in first we are focusing on Pakistani Market in which:

How far has omnichannel retailing progressed within the Pakistani Fashion Industry?

With extension questions

What are the Pakistani retailer's potential towards omnichannel retailing in terms of business transformation, organizational influence and adoption of Data and Analytics?

And Final outcome

What are the outcomes for both Retailer and Consumer perspective and How we going to link the both? Second, focusing on Consumer perspective in terms of using omnichannel, and we are adopting UTATU2 model (Venkatesh et al., 2012) to check the relation between their Purchase intentions and Hedonic motivations, Personal innovation, Habits, Social influence, effort expectance, performance expectancy and security of the customer to 
evaluate how much they are willing to switch their buying behavior to experience omnichannel.

\subsection{Limitation}

The Limitation of our studies is that we targeted multi-channel retailers who are using more than one channel to operate in Pakistan fashion retail, also the main focus is on apparel based fashion brands, some major Textile export also included in our digital surveys because to know their intentions and opinion related with omnichannel and its future scope in Pakistan, we avoid pure players ${ }^{1}$ and Brick and Mortars ${ }^{2}$ retailers also we picked selected retailers from such a huge number of Fashion retailers in Pakistan.

\section{Omnichannel Retailing}

Omnichannel retailing is an extension of multichannel retailing which demonstrate complete integration of all of the channels (e.g. Mobile, Internet, brick and mortar, etc.) Omnichannel is "integrated sales experience that melds the advantages of the physical stores with the information-rich experience of online shopping" Rigby (2011). However, Verhoef et al., (2015). argue that it consists of "synergistic management of the numerous available channels and consumer touch points, in such a way that the consumer experience across channels and the performance over channels is optimised". Online and offline both channels have its own numerous advantages which are worthy and different from each other in terms of experience (Grewal et al., 2004; Agatz et al., 2008; Rigby, 2011). Although it has arguing that online channel can support in different ways to offline channel and outcomes in terms of different types of synergy for all retail channels with increase in integration (Agatz et, al., 2008; Herhausen et al., 2015) Hence an effective omnichannel execution is purely focused on consumer value in their shopping experiences. (Herhausen et al., 2015).

Omnichannel retailing is purely based on advanced technology development which allows increased in integration for the different retail channels. Shoppers also change their shopping pattern due to the use of technology and availability of e-commerce (Kumar et al., 2012). Retailers should focus on all new technologies (Smart phones, Tablets) when designing their new strategies for consumer (Brynjolfsson et al., 2013; Frazer \& Stiehler, 2014). Consumers are more knowledgeable and have ability to connected more easily to the global market place to check different products and compare prices, this make consumers ever more demanding (Piotrowicz \& Cuthbertson, 2014). This having great impact in their purchasing pattern "consumers are combining various channels and approaches, searching online to buy offline, searching offline to buy online - and everything in between" (Oh, et al., 2012). Today using of multiple channel for a single purchasing is become more and more common. (Kalyanam \& Tsay, 2013). This is concept of "webrooming" refers consumer first search online for the products then purchasing it from store, retailers also used this strategy to increase store-traffic by provide store inventory and location on their website (Bell, Gallino \& Moreno, 2014). It enhanced efficiency of the online information that allows customer to search product from home online and then go for physical store to check physically aspects of the product and if satisfied so purchase it (Brynjolfsson et al., 2013).

As argued by Galbraith, (2005). "Today, nobody owns the consumer. The consumer owns you" this is true for nowadays. Consumer are dominantly influential on retailers these days so retailers must have to think more towards their ease and give value to them (Agatz et al., 2008). Therefore, the retailer must "organize around the consumer" and this requires closer interaction with consumer across all channels in order to gain reliability in consumer eyes (Galbraith, 2005). Nowadays Fast shifting in consumer trends and demands and challenging economy give difficult times to retailers for survive and it has to move towards to give consumer more values to gain long-term growth, profitability and consumer loyalty (Gummesson, et al., 2008). Also retailers should be willing to transform their business models which adds more value to the consumer so it would give them a competitive advantage over their competition (Teece, 2010).

Omnichannel retail emerged from multichannel, Multichannel found weak in terms of doing business, author argues Omnichannel "... will break down old barriers such as geography and consumer ignorance. Hence, it will become critical for retailers and their supply-chain partners in other industries to rethink their competitive strategies." (Verhoef et al., 2015).

\footnotetext{
${ }^{1}$ Retailers who just consider the online channel to sale their goods and services

${ }^{2}$ Retailers who just consider physical store to sales their goods and services
} 
(Table 1) is to describe Multichannel and omnichannel retail differences:

\begin{tabular}{|l|l|l|}
\hline Table 1: Multichannel Vs. Omnichannel \\
\hline \hline Theory & Multichannel Retailing & Omnichannel Retailing \\
\hline Channel Range & Take all channel as different unit & Integration of all the channels as one \\
\hline Customer connection focus & $\begin{array}{l}\text { Retail channels: store, website, } \\
\text { and mobile channel }\end{array}$ & $\begin{array}{l}\text { Retail channels: store, website, mobile } \\
\text { channel, social media, customer } \\
\text { touchpoints }\end{array}$ \\
\hline Goals & $\begin{array}{l}\text { Channel Goals (sales per channel, } \\
\text { experience per channel) }\end{array}$ & $\begin{array}{l}\text { Integration to offer a valued customer } \\
\text { experience }\end{array}$ \\
\hline Channel Function & Multi-channel chemer-retail channel-brand \\
\hline Channel Administration & $\begin{array}{l}\text { Every channels and customer } \\
\text { touchpoints geared toward } \\
\text { optimizing the experience } \\
\text { separately }\end{array}$ & $\begin{array}{l}\text { Synergies between all the channels and } \\
\text { customer touchpoints to optimizing the } \\
\text { integrated experience }\end{array}$ \\
\hline Distinguish relationship & $\begin{array}{l}\text { Distinguish relationship with the } \\
\text { channel }\end{array}$ & Distinguish relationship with the brand \\
\hline Customers & Stimulate interaction not possible & Can stimulate complete interaction \\
\hline Retailers & $\begin{array}{l}\text { Not provided integration in their } \\
\text { all channels }\end{array}$ & $\begin{array}{l}\text { Have to provide full integration in their all } \\
\text { channels }\end{array}$ \\
\hline Sales team & $\begin{array}{l}\text { Cunnot able to add value to the } \\
\text { Can Add more value by understanding } \\
\text { each customer's needs and knowledge for } \\
\text { the product }\end{array}$ \\
\hline
\end{tabular}

Source: Based on Rigby (2011), Piotrowicz and Cuthbertson (2014), and Verhoef et al. (2015).

\section{Conceptual Framework}

\section{Figure 1: Retailers Model}

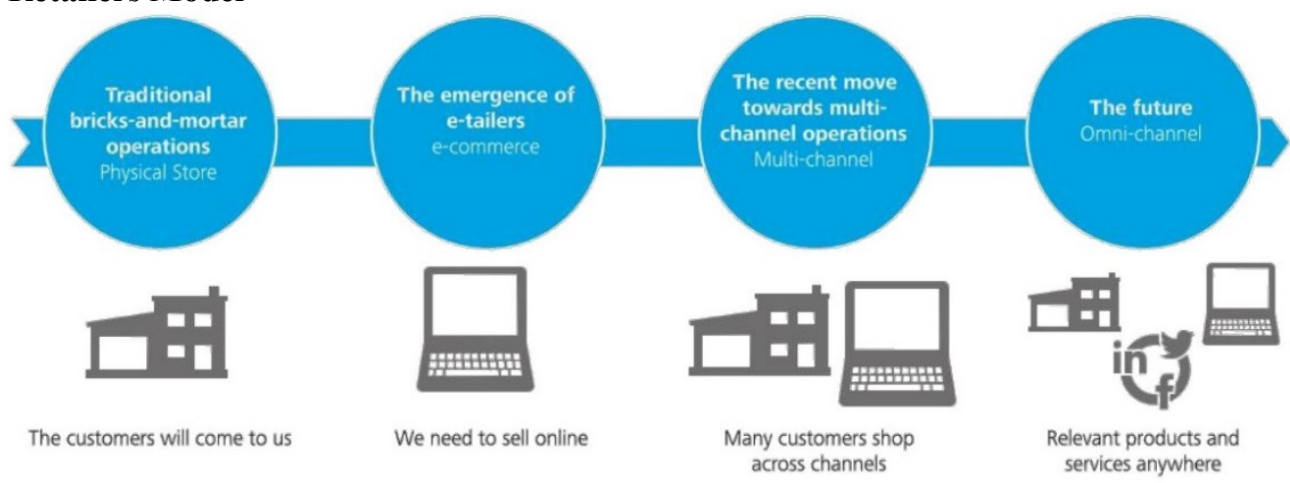

Figure 2: Consumer Model

Fig 1: Source: Evolution of Omnichannel retailing (Deloitte, 2015).

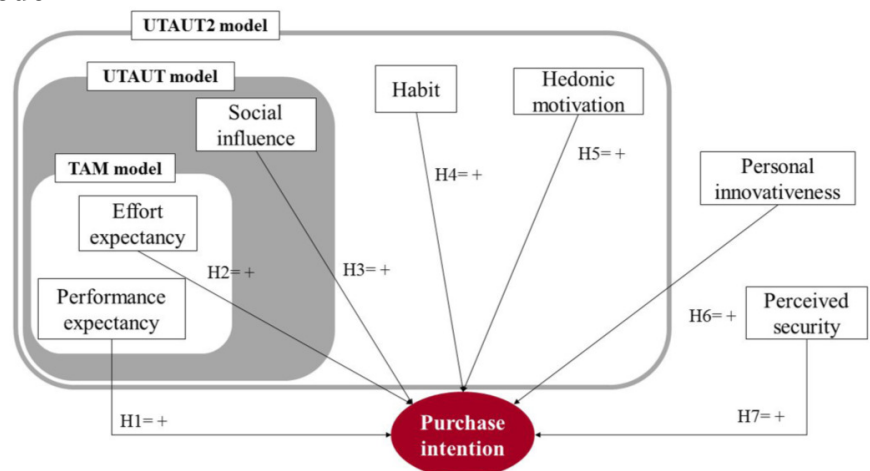

Fig 2: Source: UTAUT 2 model (Venkatesh et al., 2012).

\subsection{Description of the proposed conceptual model}


This model contains TAM model (Davis, 1989; Davis et al., 1989). (performance and effort expectancy) and UTAUT (social influences) with UTAUT2 (Habit and Hedonic Motivation) and additional 2 constructs Perceived Security and Personal Innovativeness.

Table 2: Variables Definition

\begin{tabular}{|c|c|c|}
\hline $\begin{array}{l}\text { Independent } \\
\text { Variable }\end{array}$ & Definition & $\begin{array}{l}\text { Dependent } \\
\text { Variable }\end{array}$ \\
\hline $\begin{array}{c}\text { Performance } \\
\text { expectancy }\end{array}$ & $\begin{array}{l}\text { "The degree to which an individual believes that applying the technology } \\
\text { will help him or her to gain in job performance" (Venkatesh et al., 2003). }\end{array}$ & \multirow{7}{*}{$\begin{array}{l}\text { Purchase } \\
\text { Intention }\end{array}$} \\
\hline Effort expectancy & $\begin{array}{l}\text { "Extent of ease connected with the use of system" (Venkatesh et } \\
\text { al. ,2003). }\end{array}$ & \\
\hline Social Influences & $\begin{array}{l}\text { "The extent to which an individual perceives that important others believe } \\
\text { he or she should apply the new system" (Venkatesh et al., 2003). }\end{array}$ & \\
\hline $\begin{array}{l}\text { Personal } \\
\text { Innovativeness }\end{array}$ & $\begin{array}{l}\text { "The degree to which the individual is willing to adopt innovations such } \\
\text { as goods and services or new ideas without communicating with others' } \\
\text { previous purchasing experience" (Midgley and Dowling, 1978). }\end{array}$ & \\
\hline $\begin{array}{l}\text { Hedonic } \\
\text { Motivation }\end{array}$ & $\begin{array}{c}\text { The feeling of cheerfulness, joy, and enjoyment, which is stimulated by } \\
\text { applying technology (Venkatesh et al., 2012). }\end{array}$ & \\
\hline $\begin{array}{c}\text { Perceived } \\
\text { Security }\end{array}$ & $\begin{array}{l}\text { "The consumer's belief about the potential uncertain negative outcomes } \\
\text { from the online transaction" (Kim, et al., 2008). }\end{array}$ & \\
\hline Habit & $\begin{array}{c}\text { "The extent to which, people tend to perform behaviors automatically } \\
\text { because of learning" (Venkatesh et al., 2012). }\end{array}$ & \\
\hline
\end{tabular}

\subsection{Selection of theory to propose the conceptual model}

From the analysis of theories and different models in the field of omnichannel acceptance for consumer perspective we acquired UTAUT 2 model (Venkatesh et al., 2012).

Venkatesh et al. (2003) developed the Unified Theory of Acceptance and Use of Technology (UTAUT) it constructs Performance Expectancy, Effort expectancy, Social Influence and that effects behavioral intentions furthermore, Venkatesh et al., 2012 proposed some additional construct like Hedonic Motivations, and Habit and suggested UATUT 2 model which can more effectively described in behavior intention and technology use specially in consumer context.

UTAUT 2 is more like to explain technology acceptance in consumer context instead of organizational use (Venkatesh et al., 2012). Also UTAUT 2 have examined in acceptance of Pad Phones (Huang et al., 2013), mobile payment (Slade et al., 2014) and mobile learning, therefore it has been selected for the theoretical foundation for the conceptual framework to understand the preference of the customer to purchase from omnichannel environment, also (Venkatesh et al., 2012). Suggested that future research should apply UTAUT 2 in different countries. In line with the recommendation of (Venkatesh et al., 2012). Other extrenal factors (perceived security and personal innovativeness) also considered with UTAUT 2 in the same model.

\subsubsection{Purchase Intention}

Behavioral intention has used as a dependent variable before in multitude studies related to technology adaptation consumer behavior (e.g. Frasquet et al, 2015; Venkatesh \& Davis, 2000; Pappas et al, 2014) and seen to effected by a different construct. Behavior Intention taken as a purchase intention in different research (e.g. Agarwal \& Prasad, 1998; Khalifa \& Liu, 2007; Juaneda-Ayensa et al., 2016)

\subsubsection{Effort Expectancy}

It relates to touchpoint technology in purchase process (Venkatesh et al., 2012; Juaneda-Ayensa et al., 2016). and it's one of the main construct of TAM Model (Venkatesh \& Davis, 2000). Effort expectancy have been seen positively influence on purchase intention in some past studies (Davis, 1989; Venkatesh et al., 2012; JuanedaAyensa et al., 2016, Pantano \& DiPietro, 2012). But to instantiate cha (2011) showed that effort expectancy did not positively influence for online items. But sufficient for items purchased offline.

\subsubsection{Performance Expectancy}

It refers value derives from using the technology (Pantano \& Di Pietro, 2012). According to Venkatesh \& Davis (2000) the performance expectancy is comparing the compatibility to of a system in a relation to the job that is to be performed. It has been considered the strongest anticipator of Behavior Intention (Davis, 1989; Venkatesh et al., 2003; Venkatesh et al., 2013; Pascual-Miguel et al., 2015; Juaneda-Ayensa et al., 2016). It was developed from perceived usefulness (San Martin \& Herrero, 2012).

\subsubsection{Social Influence}

It conducts as a direct construct which effects on behavioral intention social influence examines in earliest research related with acquiring technology (Fishbein and Ajzen, 1975; Schifter and Ajzen, 1985; Davis, 1989; Davis et al., 
1989; Moore and Benbasat, 1991). Social influence is the predictor of behavioral intention as how people believe or take others views related with acquiring technology and it's positively affect purchase intention. (Venkatesh et al., 2012).

\subsubsection{Hedonic Motivation}

"what consumers want and believe they get from buying and using a seller' product" (Woodruff, 1997). Now a day's consumer wants convenience in their shopping experience and it's need for retailers as well to understand the motives for shopping to generate value for the customers. Hedonic shoppers are driven by entertainment and different set of human motivations (Rintamaki et al., 2006). When shoppers are shopping for hedonic product they are in a "play" mindset (Babin, Darden, and Griffin, 1994). hedonic motivation was included as a separate construct in UTAUT2 (Venkatesh et al., 2012). Some previous research on ICT shows the relationship of hedonic motivation on purchase intention and acquire the technology (Van Der Heijden, 2004; Thong et al., 2006).

\subsubsection{Habit}

Habit refers a repeated behavior for some certain situation (Aarts et al., 1998; Ouellette \& Wood, 1998). Habit has been tested as an influencer on purchase intention by some scholars (Chiu et al., 2012; Khalifa \& Liu, 2007). Some scholars taken it as a moderate predictor of shopper behavior intention which either supported or un supported the relation of using technology and behavior intention (Venkatesh, 2012; Ji \& Wood, 2007; Juaneda-Ayensa et al., 2016; Agag \& El-Masry (2016) and Ji \& Wood (2007). It also indicates the online repurchase intention (Khalifa \& Liu, 2007). Increasing experience would be influence the behavioral intention either positive or negative depends upon the nature of the experiences and difficulty or ease to use for the consumer while develop their purchase intention (Venkatesh \& Bala, 2008). and habit is formed through repeated experiences.

\subsubsection{Personal innovativeness}

Innovativeness consider individual specific trait that one has by-birth with higher and lower degree (Xu \& Gupta, 2009). In different context innovativeness has been used as a predictor which influence on purchase intention (Escobar-Rodríguez \& Carvajal-Trujillo, 2014; Juaneda-Ayensa et al., 2016; San Martin \& Herrero, 2012). Several previous studies based on consumer behavior took innovativeness as a moderating variable in terms of adopting technology but Xu \& Gupta (2009) and Rogers (2010) argue that innovative consumer are more complex because of their extended knowledge of technology and personalize software. Agarwal \& Prasad, 1998 indicate it negative effect on purchase intention while Herrero \& Rodriguez del Bosque (2008) and Rogers (2010) argue that highly innovative people can effectively deal with uncertainty and willing to acquire new technology more.

\subsubsection{Perceived Security}

Consumer may not feel comfortable to provide their personal information online to the retailers due to security concern (Yenisey et al., 2005). The privacy is the main concern which will be in debate from previous researches, some scholars taken it as a positive influence in online purchase intention (e.g. Salisbury et al., 2001 and Frasquet et al., 2015) and some research shown (e.g. Kim et al., 2008; Fortes \& Ritas, 2016) negatively effects on purchase intention, Although Juaneda-Ayensa et al. (2016) show that within the clothing industry security did not possess any significant effects. However, perceived security refers to belief that it's not harm to share personal information through internet (Cha, 2011; Escobar-Rodríguez \& Carvajal-Trujillo, 2014).

\subsection{HYPOTHESIS:}

H1: Performance expectancy positively influence omnichannel purchase intention

$\mathrm{H} 2$ : Effort expectancy positively influence omnichannel purchase intention

$\mathrm{H} 3$ : Social influence positively influence omnichannel purchase intention

H4: Hedonic Motivation positively influence omnichannel purchase intention

H5: Habit positively influence omnichannel purchase intention

H6: Personal Innovativeness positively influence omnichannel purchase intention

H7: Perceived Security positively influence omnichannel purchase intention

\section{RETAILER PERSPECTIVE}

\section{METHODOLOGY}

In this research to answer the empirical data three methods are being used: Interviews, Field research and digital survey. The main purpose of this research was to find out the growth and development of Omni channel with in Pakistan fashion retail industry. For the purpose of getting the information regarding the Omni channel 25 multichannel were being surveyed and interviewed with in the respective industry

Field research was used to get the base line of Omni channel that what are the current offerings of omnichannel. (Appendix 1) shows the number of observations of the quantitative data used to predict certain offering limits which are provided by retailers.

On the other hand, digital survey was conducted to know the views about the organization regarding the Omni channel retailing. The methods also provide the inside views of 3 key areas of business: organization, application of data and analytics, business transformation. 
Last but not the least interviews were conducted with retailers to know that how they approach the area.

\subsection{Field Research}

Collection of information outside a work environment in order to examine target market (Burgess et al. 1989). The purpose of the Field research was to evaluate the current offerings of Omni channel given by selected retailers and for this purpose 54 Omni channel parameters were selected with in 5 areas: channel synchronization, loyalty and customer service, fulfillment, frictionless online experience. These parameters were chosen from previous research Avensia (2015) and NRF (2016). All of these parameters are evaluated by physical and personal observations also some retailers contacted during the observation where information is difficult to collect through observation and all the results was noted in spreadsheet to keep the record of the process and final index is created after summarizing all the results and findings.

\subsection{Survey}

Survey was conducted explore the retailer's attitude towards Omni channel and for this purpose 25 companies were selected and emails have been sent to them with the attachment of the questionnaire created on google forms. The selected scale was 1 , strongly agree 2 , agree 3 , neutral 4 , disagree 5 , strongly dis agree. When conducting any research there are always the risk of errors

\subsection{Interviews}

Three different retailers were interviewed to get the depth knowledge about the Omni channel

The retailers were interviewed on call the interviewee's names are not mentioned as it is kept confidential similarly the questions of the interview are also not notified as this interview was not structured

\subsection{Sample Selection}

Under this section, criteria are defined according to which sample companies are selected, the criteria s under which the companies should fall in order to be the sample for this research are as follows:

1. Should be Present in Pakistani market or potential to enter in a market.

2. Should be related to fashion or Textile industry.

3. Should operate in more than one channel.

The following 25 companies come across to fulfill the above criteria and were nominated to contribute in the study:

Table 3: List of Selected Retailers

\begin{tabular}{|l|l|l|l|l|}
\hline \hline J. & Kayseria by Bareeze & Oaks & Lucky Textile & Chase up \\
\hline Khaadi & Ideas by Gul ahmed & Amir adnan & Zellbury & Mausummery \\
\hline Sana safinaz & Zainab chootani & Sapphire & Younus Textile & Satrangi by Bonanza \\
\hline Maria B & Nishat linen & Edenrobe & Firdous & Threads and motifs \\
\hline Alkaram & Ethnic by outfitters & Warda & Cambridge & Shamrafs Clothing \\
\hline
\end{tabular}

\subsection{Measurement Errors:}

As with all researches, this may also subject to errors with regards to Methodology ${ }^{1}$, Sampling $^{2}$, Non-Sampling ${ }^{3}$, Response $^{4}$, Non-response ${ }^{5}$, and Observations ${ }^{6}$

\section{FINDINGS}

The results are divided into categories of current omnichannel development and potential towards further development of omnichannel in Pakistan Fashion Retail Industry

\subsection{Current Omnichannel Development}

From Field Study analysis, an overview for omnichannel development of the 22 multi-channel textile retailers in Pakistan. It evaluates 54 different parameters (appendix 1) from five different areas to conclude the current omnichannel development from customer perspective.

\section{Omnichannel index for Multi-Channel Retailers}

\footnotetext{
${ }^{1}$ Expected errors that might be exist in the methods that has been used

${ }^{2}$ Error take place when a sample is observed instead of the entire population, since no sample is a faultless representation of a given population

${ }^{3}$ Non-sampling errors are the collected term for all errors caused by deviances from the true value that are not a function of the nominated sample

${ }^{4}$ When a respondents provide intentionally or unintentionally an inaccurate answer.

${ }^{5}$ When a person cannot participate or refuse to participate in a survey due to any reason.

${ }^{6}$ Difference between observed and true value, this error can be occurring due to technical tool used for measuring and by the researcher in observation process.
} 
The sample group fulfilled $27 \%$ of the total omnichannel criteria (Fig. 3 ) with the highest being $44 \%$ and the lowest is $10 \%$. Those Textile groups which are just focusing on export are excluded from field study so the sample size is reduced to 22 from total 25 which are included in surveys.

\section{Fig. 3: Omnichannel Index}

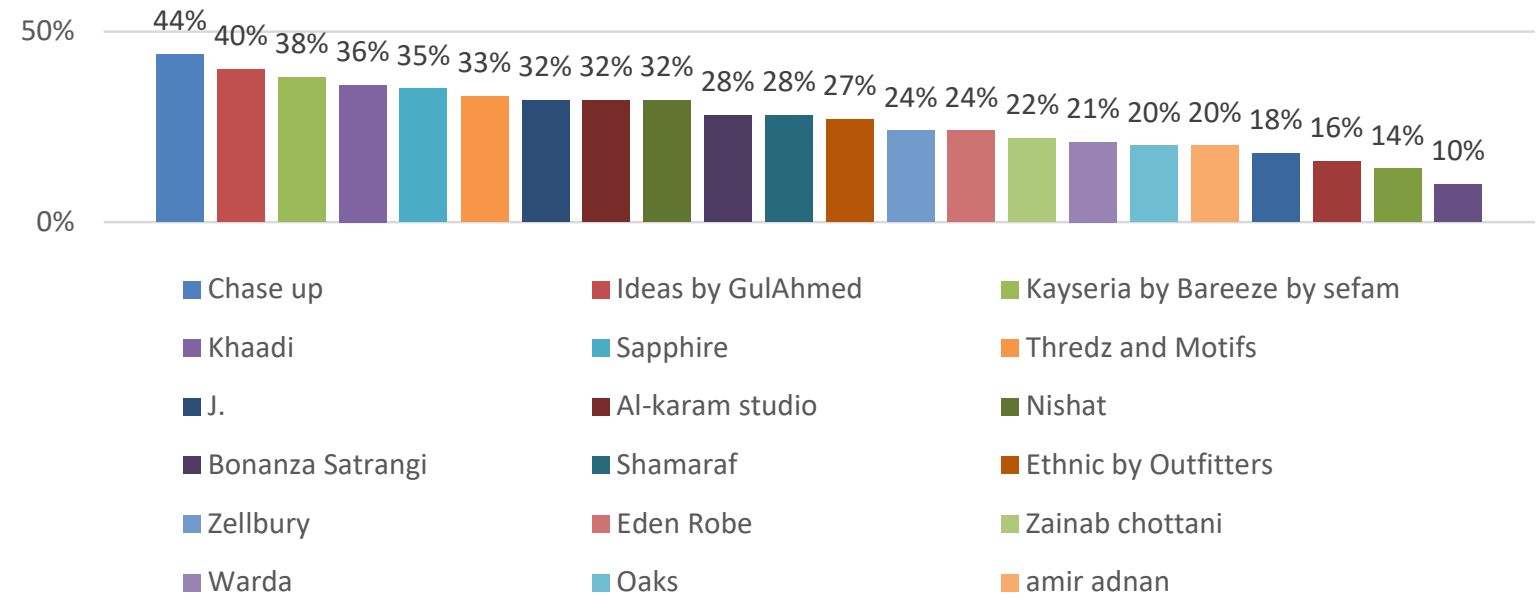

\section{Stages at the omnichannel Journey}

In observation the average score of $27 \%$ for development of omnichannel in Pakistan fashion retail. Fashion retail stores which is in between $10 \%$ to $22 \%$ are seeking as lowest in omnichannel scale because majority have not sufficient in terms of providing integration in all of its channels also from our finding we observed that some are not focused in term of maintaining their mobile apps and software. Second category range is from $24 \%$ to $30 \%$ are those textile retailers who have number of outlets and using multiple channels but weak in terms of integrating and updating their channels to give customer a unified experience Third Category range is from $30 \%$ to $36 \%$ are those retailers who have using multi-channel and good in updating their channels but these retailers are consider in the Solo mode stage because of using different business models for different channels rather to focus on perfect integration to provide seamless experience, the last category is from above $40 \%$ in which Ideas and Chase up, although Ideas found in minimal integration and used different business models for different channels but they are good in terms of updating their all channels in terms of their new arrivals and sales promotions but weak in terms of collecting customer data and providing omnichannel environment to their customer. Chase-up is seeking far way better than other and in between minimal to moderate in terms of integrating their channels as well as collecting customer information and data, which is more important in Omnichannel Journey to targeting your customer more accurately in terms of their needs provide seamless and unified shopping experience.

\subsection{Development of Specific Omnichannel Areas and Parameters}

We observed 54 parameters that are importantly influenced in Omnichannel development, these parameters are further divided into 5 categories which are: omnichannel fulfillment, Channel Synchronization, frictionless online experience and loyalty of the customer service and the relationship management.

\section{Omnichannel Fulfillment}

Fulfillment related with availability in store and return \& delivery. The availability part related with the relation of e-commerce and physical store. This feature helps to product inventory information online and to touch and check the product in store before purchase. The Return \& Delivery Part focused connection flexibility and the transaction and product acceptance process. The score in total fulfilment category was $26 \%$ in which availability in store score was $24 \%$ and delivery \& return found $28 \%$.

\section{Fulfillment: Availability in Store}

A Foundation feature for omnichannel which connecting the online and offline stores and allowing customer to experience different channels for shopping. The section shows that $48 \%$ retailers provided this services to the customer but not with full extent like provide it in real time, also just $45 \%$ of the total using mobile apps facilities for the customer in which only Chase up taking it an advantage of GPS yet (Fig. 4). 


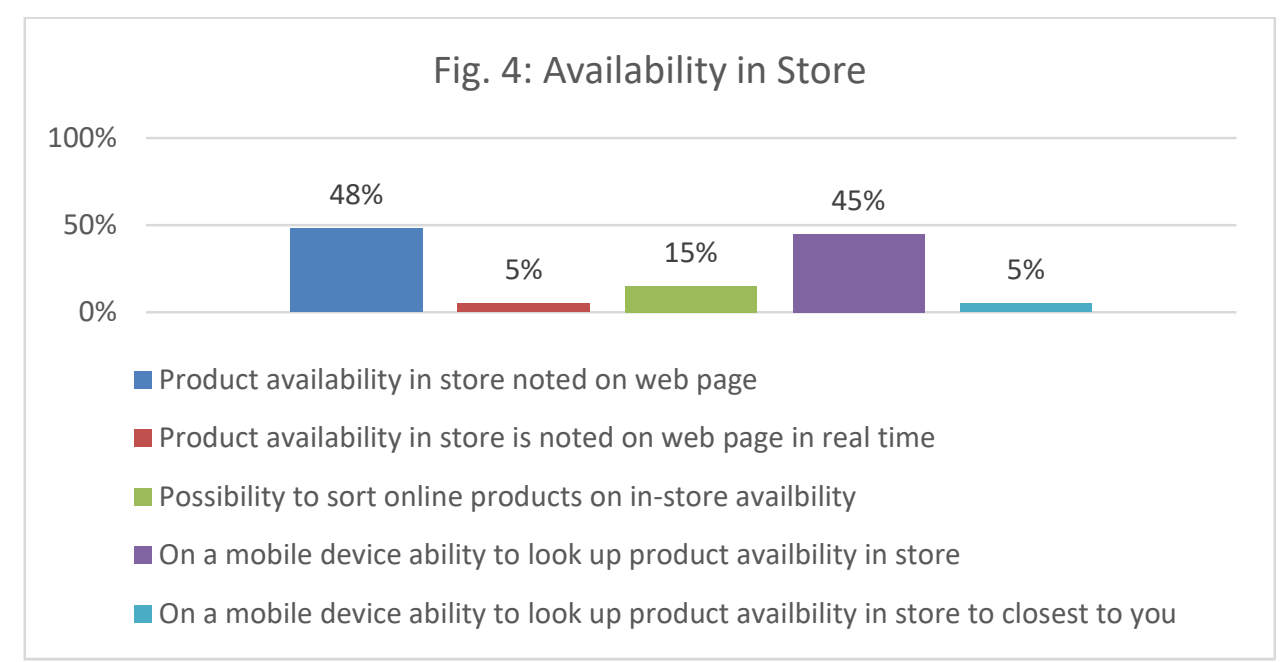

By Summing up this data it is clear that still $52 \%$ retailers still need to development the first stage of omnichannel journey also those who are using these features and on the first stage they also need an improvement related with real time information which is mandatory for Omnichannel stores to aware customer related with real inventory available in store also they can take location based advantage to sales more by targeting the customer with push out notifications and sms offers nearby the stores.

\section{Fulfillment: Delivery \& Return}

This Delivery and return focusing the product buying online and pick up in store (BOPIS) or Click \& Collect, this is extension in availability of product in store service. This adds logistics and transaction part which makes it more complicated. Not every retailer offers this service except big Brands but some brands using other offers like replace the product or deduction $10 \%$ to $20 \%$ for returning the product.

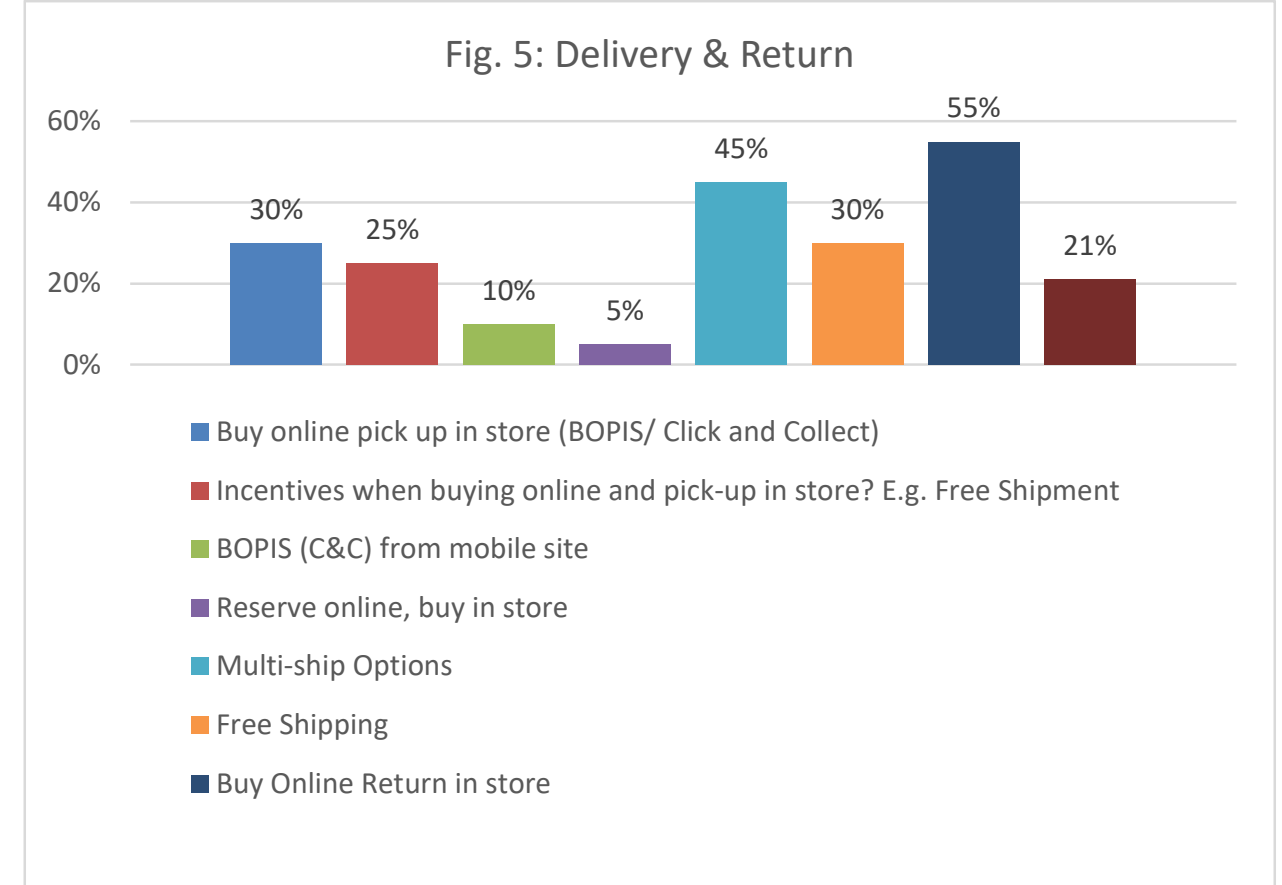

The features like Multi-shipping and BORIS $45 \%$ and 55\% respectively (Fig. 5) is far better and developed as compared to others parameters in Pakistani Fashion Retail, in terms of shipping, some big retailers added cost prior in the price but offer Free-shipping on both delivery and return. 6 retailers offer buy online and pick up in store services and 5 offers incentives of free shipping as well, only one retailer yet offering reserve online and pick up in store offer.

\section{Channel Synchronization}

It holds Several parameters which have potential to produce unified shopping experience for the customer and help in providing a better omnichannel environment. More than 50\% using same price and offer in online and offline stores, other parameters like shopping cart transfers and functionality to write a shopping list online then bring it to Brick and Mortar store is just $10 \%$. On the other end services like cross channel gifts/coupons and access to 
additional information about product through QR code found 20\%, in-store signage about the omnichannel and possibility to order from online assortment from device in physical store found $0 \%$ (Fig. 6), Through our selected samples almost half of the retailers have mobile applications that customer can use to purchase online and majority has mobile optimize websites, few retailers provide wifi services in store and some have stores in Shopping mall too where they can utilize wifi services for their customer.

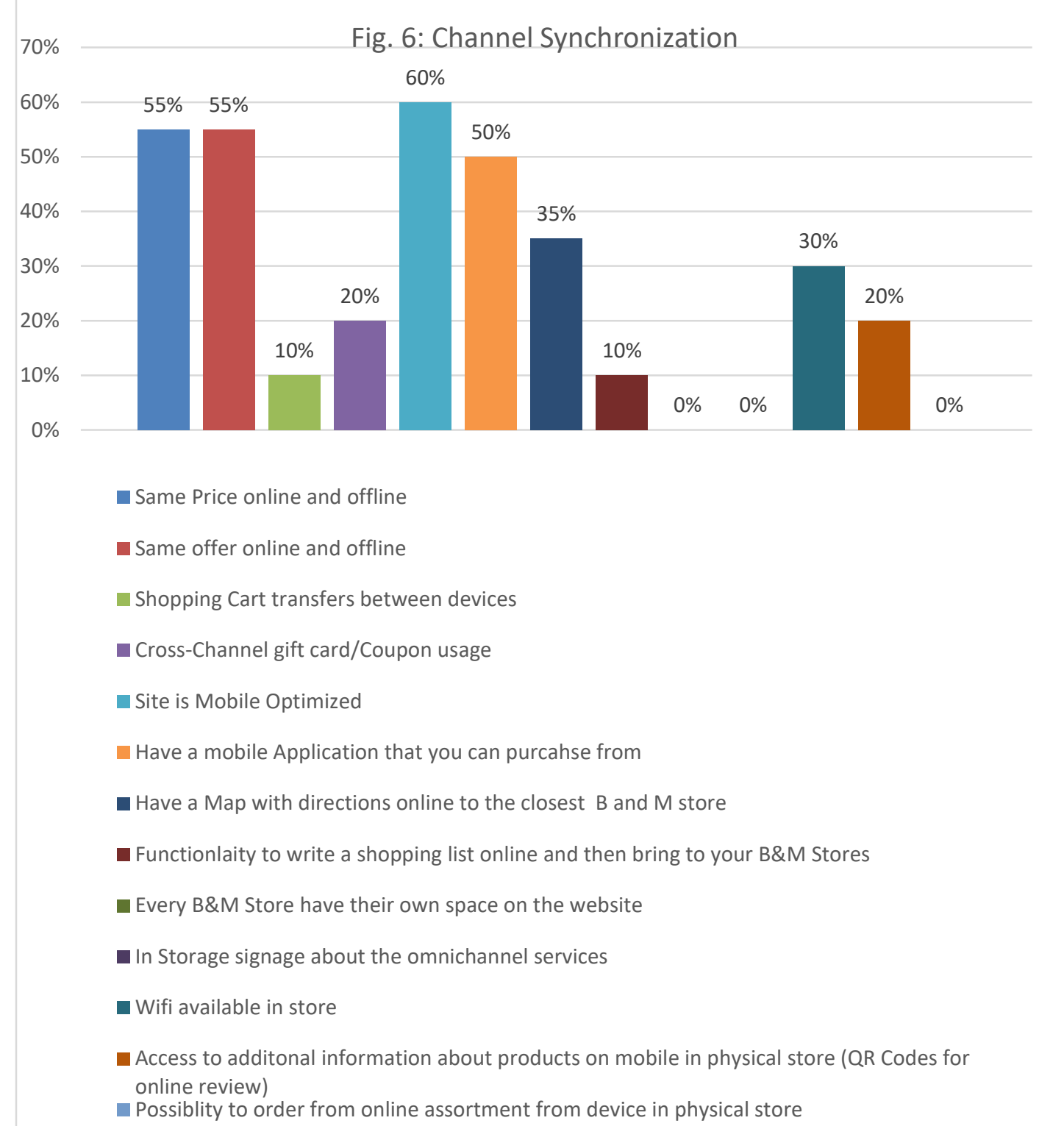

By observing the percentage of parameters, it's quite clear that there is still need of lot of effort required in terms of improve channel synchronization as $40 \%$ of the retailers not even have mobile optimize website also many retailers not focusing on to develop their mobile apps for customer to purchase their product, even most of the retailers are working on E-commerce but in term of integration their channel just Few takes initiative to move as a Pioneer in omnichannel journey in Pakistan Fashion Retail yet. 


\section{Frictionless Online Experience}

Fig. 7: Frictionless Online Experience

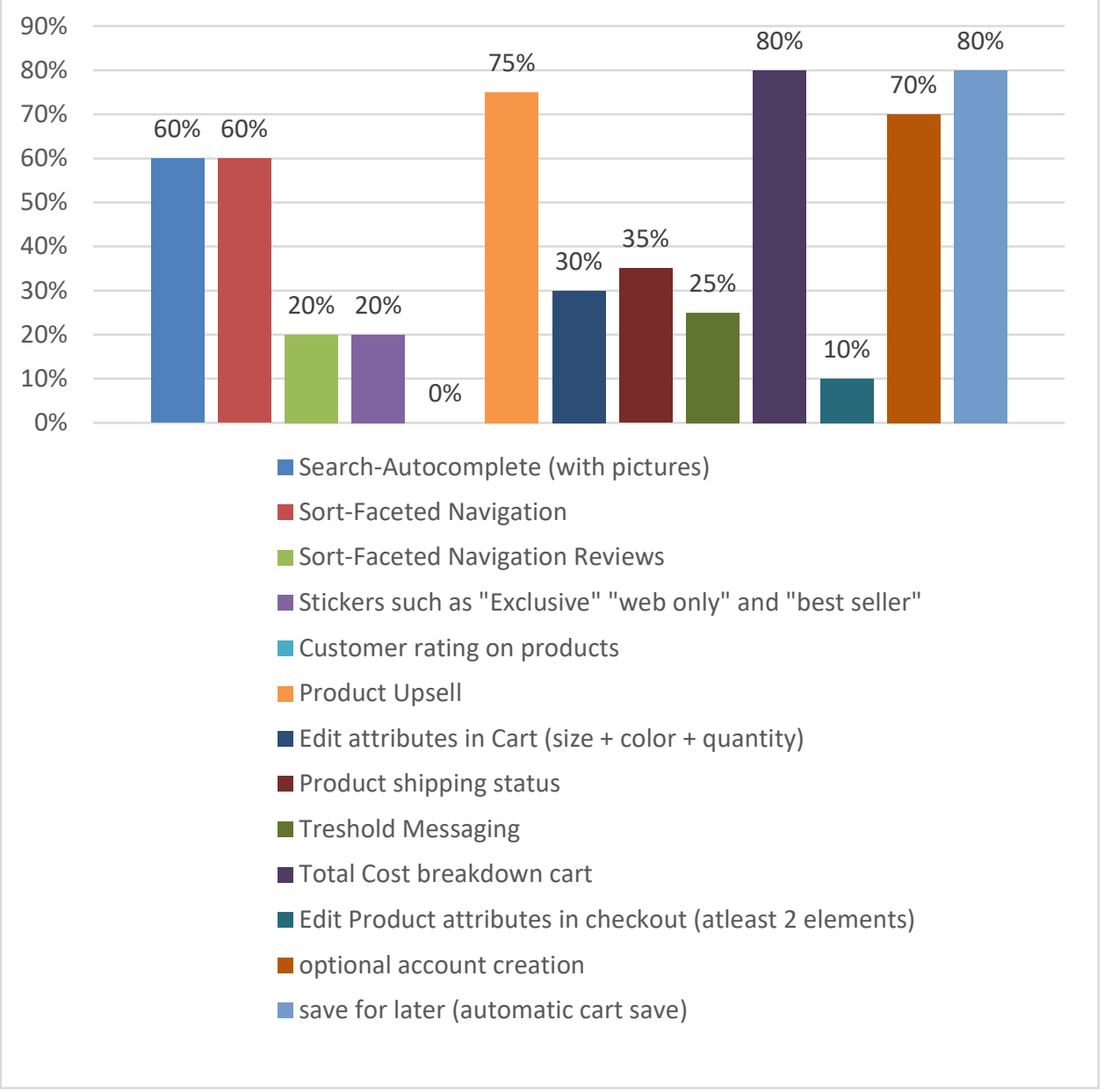

The results (Fig. 7) conclude that E-commerce site is far better $43 \%$ in terms of omnichannel view as compare to other categories but there is need of working on customer ratings on products parameter which is not focusing by any retailer due to its profit oriented approach rather to focus on customer oriented approach.

\section{Omnichannel Loyalty Services}

Fig. 8: Customer Loyalty services

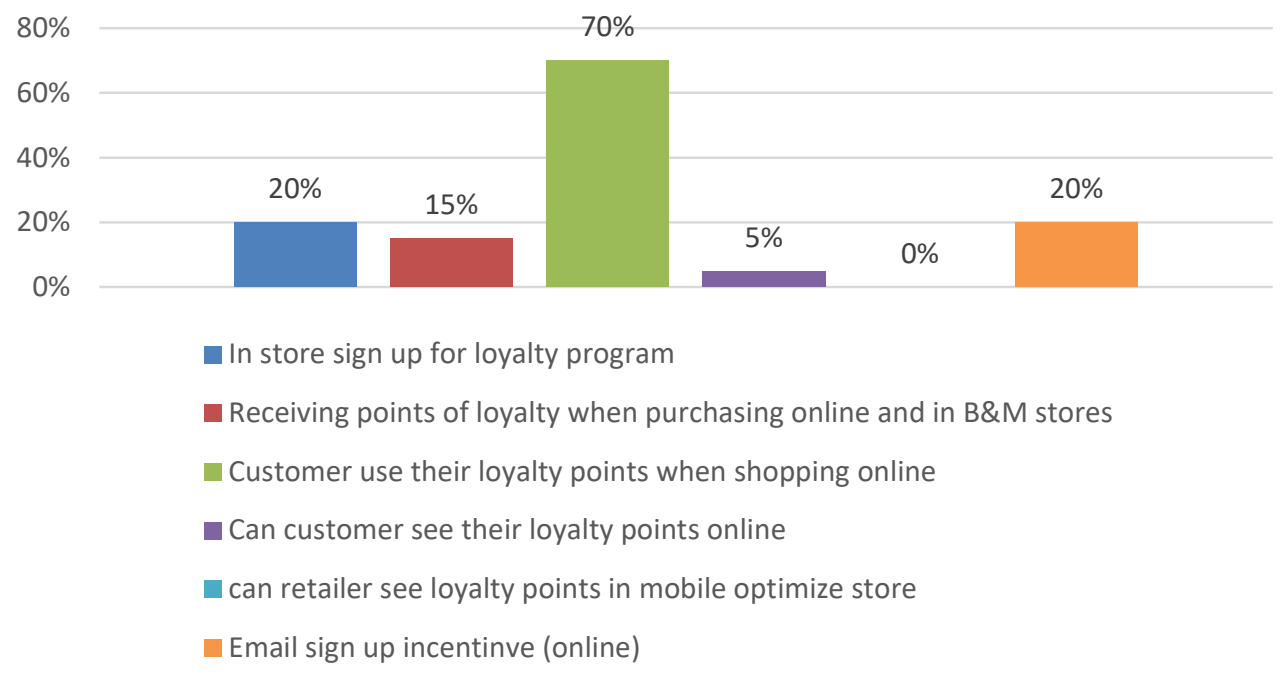

No any Fashion retailer focusing on to give loyalty points to their customer or working on any loyalty program 
for customer (Fig. 8), but few offer some sign up incentives online, Only Fashion designer using this attributes for their selected loyal customer to give them loyalty benefits in terms of discount offerings although in Pakistan customer love to take loyalty points and discounts to use in their shopping experience.

\section{Omnichannel Customer Service}

Customer services is important in terms of omnichannel retailing, it should provide convenience for the customer, $45 \%$ of the retailer provide customer services link at their front page while $20 \%$ customer service option noted in checkout (Fig. 9), majority of retailers provided Email support at their website which seems better as compare to other parameters. Live chat options also using by some pioneer and big Giant of Fashion retailers in Pakistan, some parameters like User Generated Question \& Answer for support and Mobile site click to call wasn't found in any retailer store or at their mobile apps

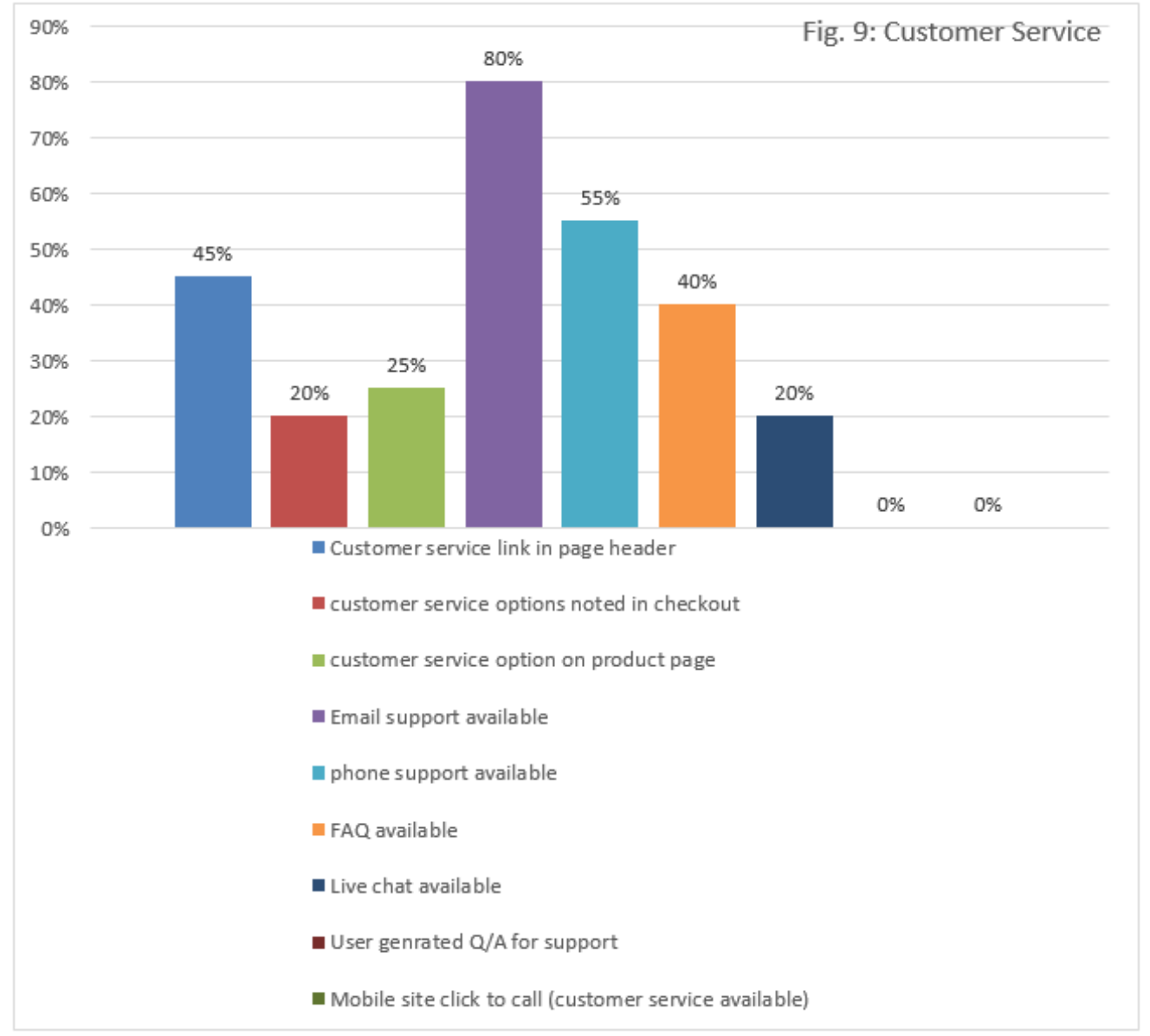

\section{Summary of omnichannel Index}

Fig. 10: Summary

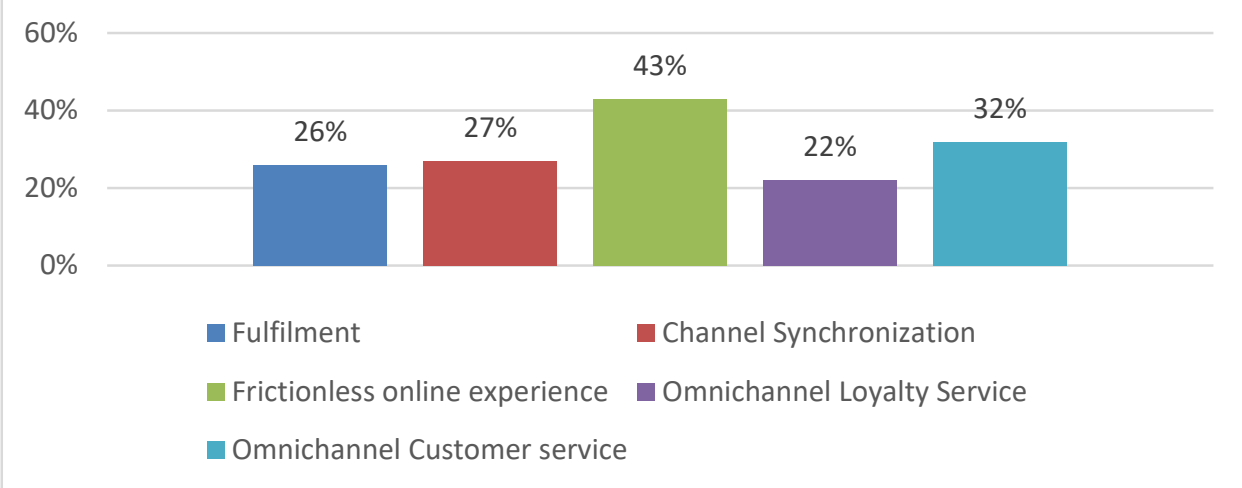

The Overall omnichannel development (Fig. 10) with in Pakistani Fashion retail seems to at very early stage, most of the retailers are in Solo stage but few found in minimal integration, but as per omnichannel archetype no 
one seems as a Pioneer of providing complete omnichannel journey although few are in Challenged multi-channel retailers.

\subsection{ATTITUDE TOWARDS OMNICHANNEL RETAILING}

We include 25 multi-channel retailers in our survey in which we took semi-structure interview from 3 of our retailers as well to get more deep inside knowledge.

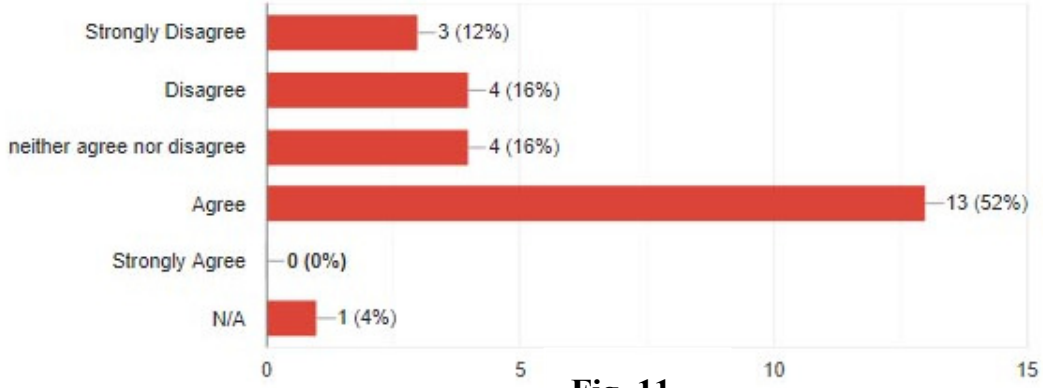

Out of the 25 retailers in the survey $52 \%$ agreed to pig. 11 fully committed to delivering omnichannel experience to the customer (Fig. 11) and belief that it would help them to give customer more values in term of their shopping experience and make customer loyal to their brand.

Pakistan is in very early stage of omnichannel retailing and there is substantial amount of retailers $(33.3 \%)$ who are planned to start working on omnichannel and some retailer $(29.2 \%)$ have started working but less than a year ago (Fig. 12).

Fig. 12

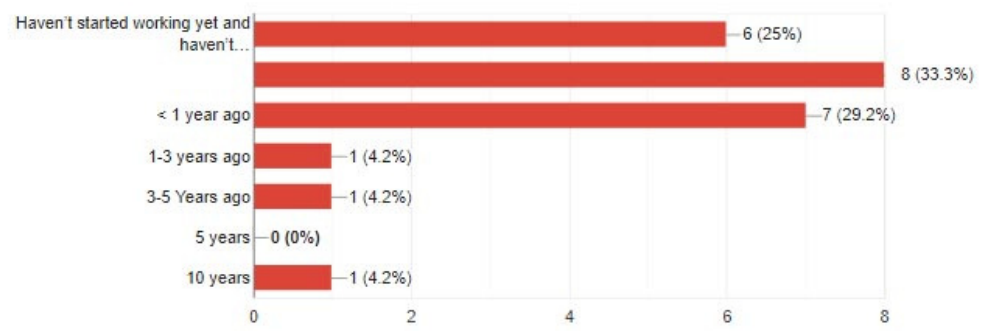

From the survey we found that the Leadership team $72 \%$ is in charge of developing or taking decision related with omnichannel although $12 \%$ agreed that this decision would belongs to CIO, CTO and COO positions, in summarize we can say that decision belongs to Top Management Team.

$35 \%$ believes to add a position of Chief Digital officer to operate Omnichannel but still almost 50\% think that this position will just an add-on in cost, our one interviewee also relates this with their marketing department rather to think for new position in their organization

"Why we need to add a position of CDO if we already have Marketing department for this concern"

\subsubsection{ATTITUDE TOWARDS OMNICHANNEL TRANSFORMATION}

Interviewee 1

This part shows the Potential of Pakistani textile and Fashion retailer towards Business Transformation More than $76 \%$ retailer agreed and strongly agreed that omnichannel retailing requires substantial re-engineering (Fig. 13), also more than $90 \%$ believe that omnichannel requires Front-end Transformation in order to give unifying experience to the customer (Fig. 14).

\section{Fig. 13}

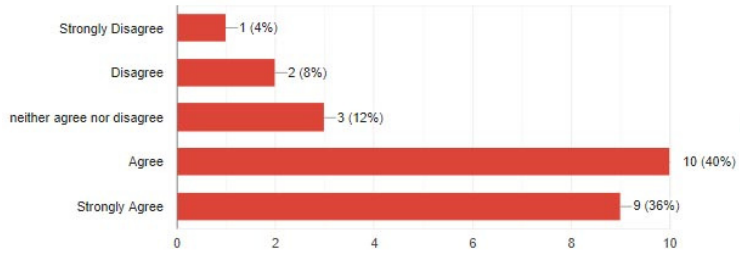

Fig. 14

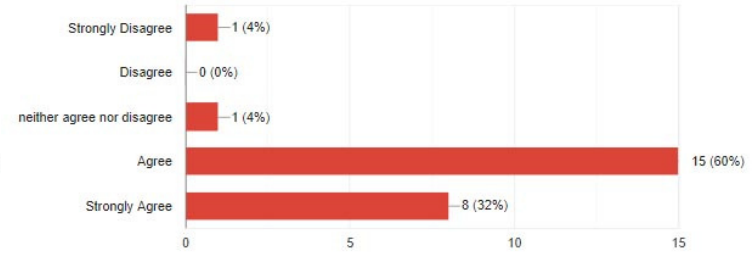

More than $80 \%$ retailers believe that omnichannel requires back-end transformation to provide seamless experience to the customer (Fig. 15). 


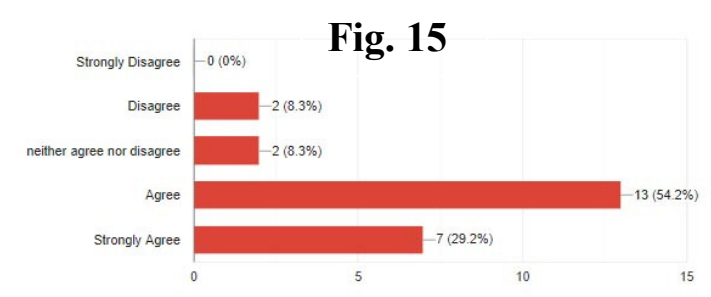

Related with shifting ability of an organization less than $20 \%$ believe that they have an agile organization and can easily shift and adapt changes to deliver an omnichannel experiences, no any textile industry agreed with that. Our 2 interviewee not seem satisfy with the transformation and feel that it's risky for their business module

"We need to change our whole business module to acquire omnichannel which can be a great risk for our business"

Interviewee 1

"Adaptation of new technology is good, but we have to calculate the risk associated with it first and will consider both positive and negative consequences of it"

\section{Risk with the omnichannel Transformation}

Interviewee 2

The greatest risk is considered lack of digital maturity with in the internal organization (68\%), the second biggest risk is associated with increased operational cost $56 \%$ although manage change of the internal organization $52 \%$ is considered as the third, other risk indication by some retailers are Uncertainties in the transformation process and upfront capital investment are $20 \%$ while risk of cannibalization of sales is rated as $12 \%$ in overall survey (Fig. 16).

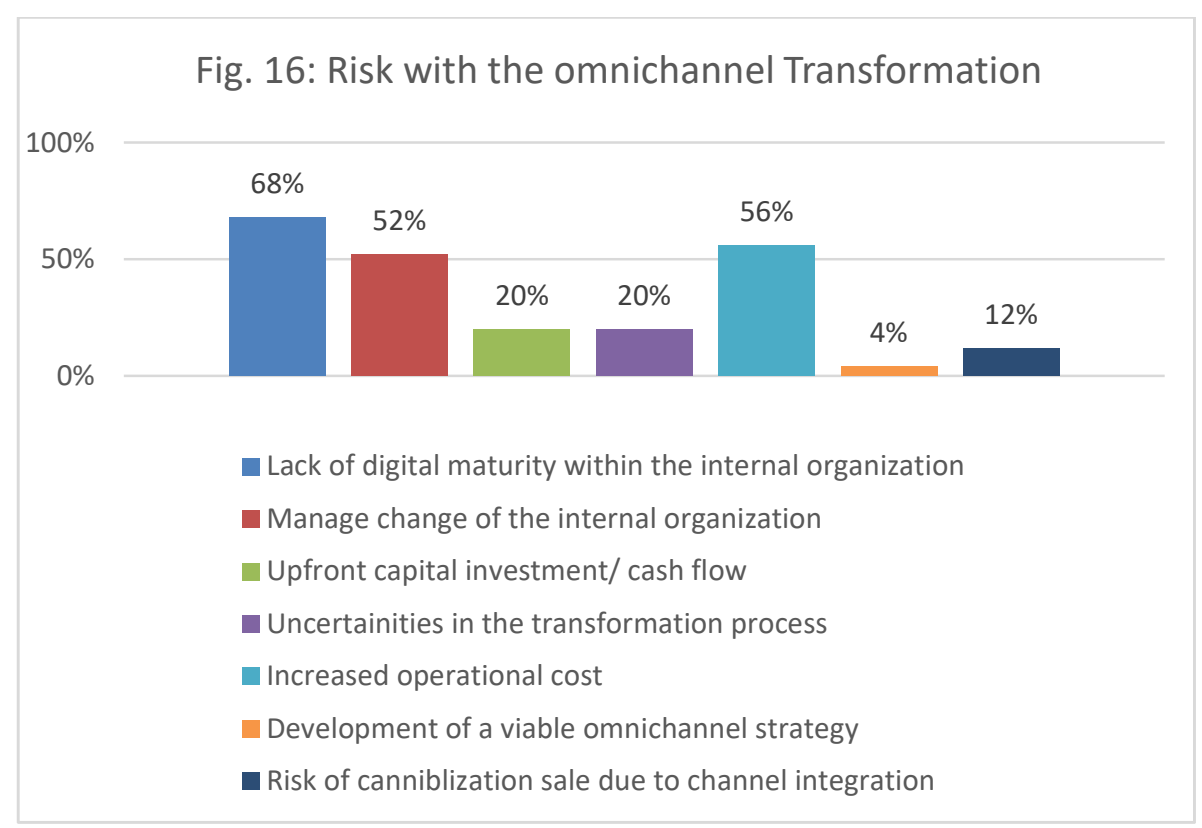

"In Transformation the real risk is associated to manage internal organization, sometimes it severely effects business module and motivations of the loyal employees"

Interviewee 2

"It's mandatory to manage and train your organization first then to move further to start loyalty program for your customer"

Interviewee 3

5.3.2 INFLUENCE OF THE INTERNAL ORGANIZATIONAs per Digital survey almost $40 \%$ disagree that transformation their business to omnichannel associated with great risk while more than $30 \%$ considering not to answer for the question and rest recorded as greatest risk in terms of providing pure omnichannel experience to their customer.

As per analysis of the survey more than $50 \%$ agree that in their organization each channel operates independently and have an autonomous business goals (Fig. 17). 
Fig. 17

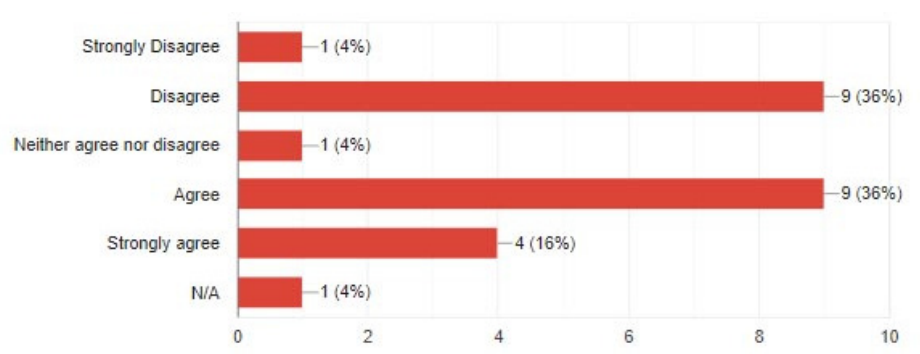

As far as modification and changes in IT environment $56 \%$ agreed and strongly agreed to planning for it while $40 \%$ disagree in which some retailers believe that their IT environments best fits with their corporate strategy and they don't need any further modification in it (Fig. 18).

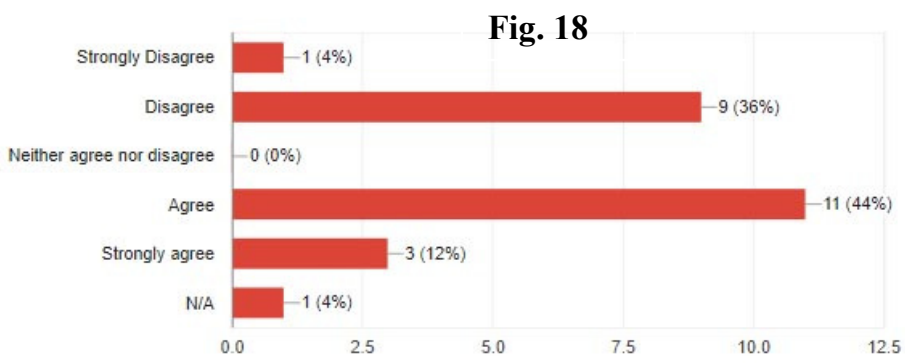

\subsubsection{ATTITUDES ABOUT DATA AND ANALYTICS}

Data and analytics are the most important factor in term of providing omnichannel journey to the customer, from digital survey we observe $52 \%$ believe that data and analytics are of great importance for their organization business (Fig. 19).

Fig. 19

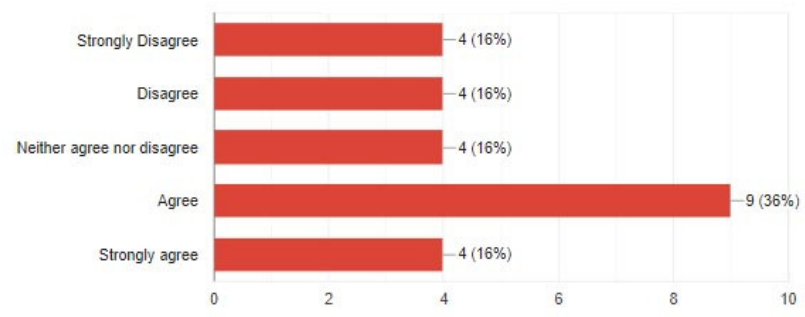

Majorities are disagreed for question related technical systems needed to extract all the relevant customer data (Fig. 20), and analytical capabilities to gain the insight of the data (Fig. 21), which means these are the weak factors that need to be work a lot in terms of optimize omnichannel in Pakistani Fashion Retail.

Fig. 20

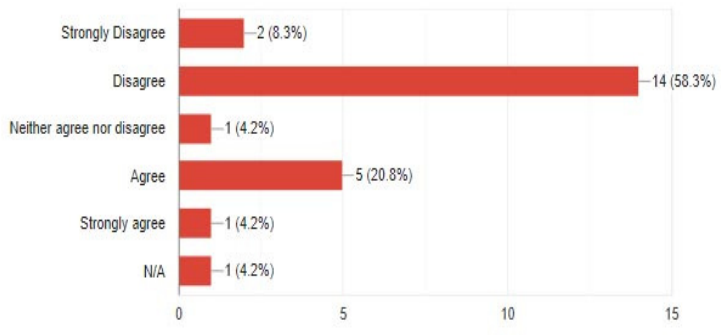

Fig. 21

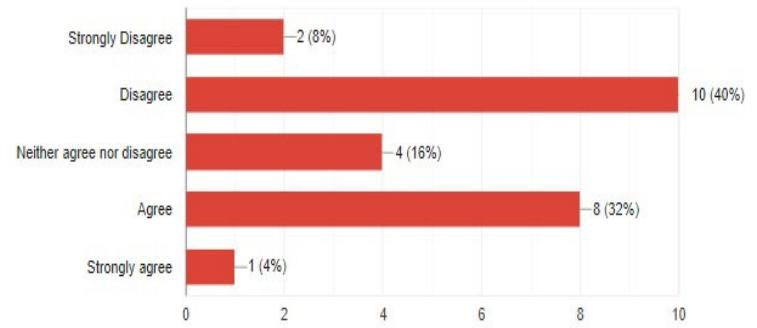

The main focusing point from data and analytics for the retailer is to understand customer behavior $68 \%$, followed by targeting promotions and offerings $40 \%$ and to digitalizing physical store $36 \%$, however data driven business decision $28 \%$, personalization of ecommerce site $28 \%$ and inventory forecasting and replenishment also seen as area of improvement for the retailers (Fig. 22). 


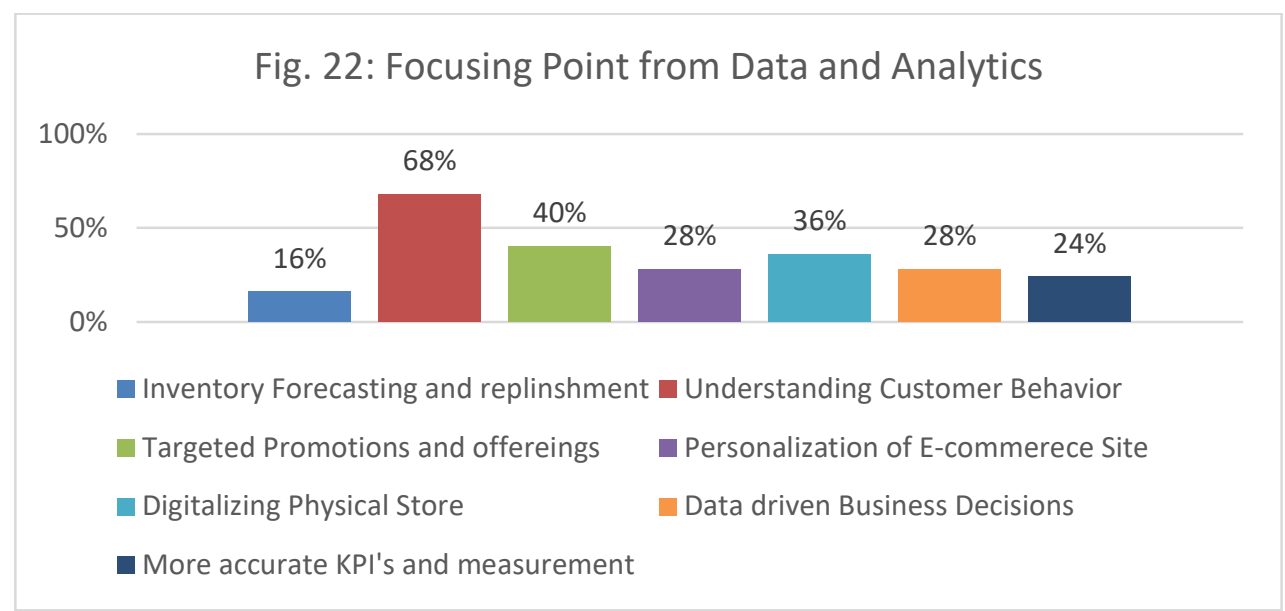

Many retailers consider to change in their E-commerce Platform 56\% and Mobile application 56\% to deliver better Omnichannel experience rather some focusing on to change their Enterprise resource Planning $52 \%$ but some gives importance to content management $36 \%$, business intelligence $36 \%$ and payment system $32 \%$ as well to modified to deliver better seamless unified experience to the customer (Fig. 23).

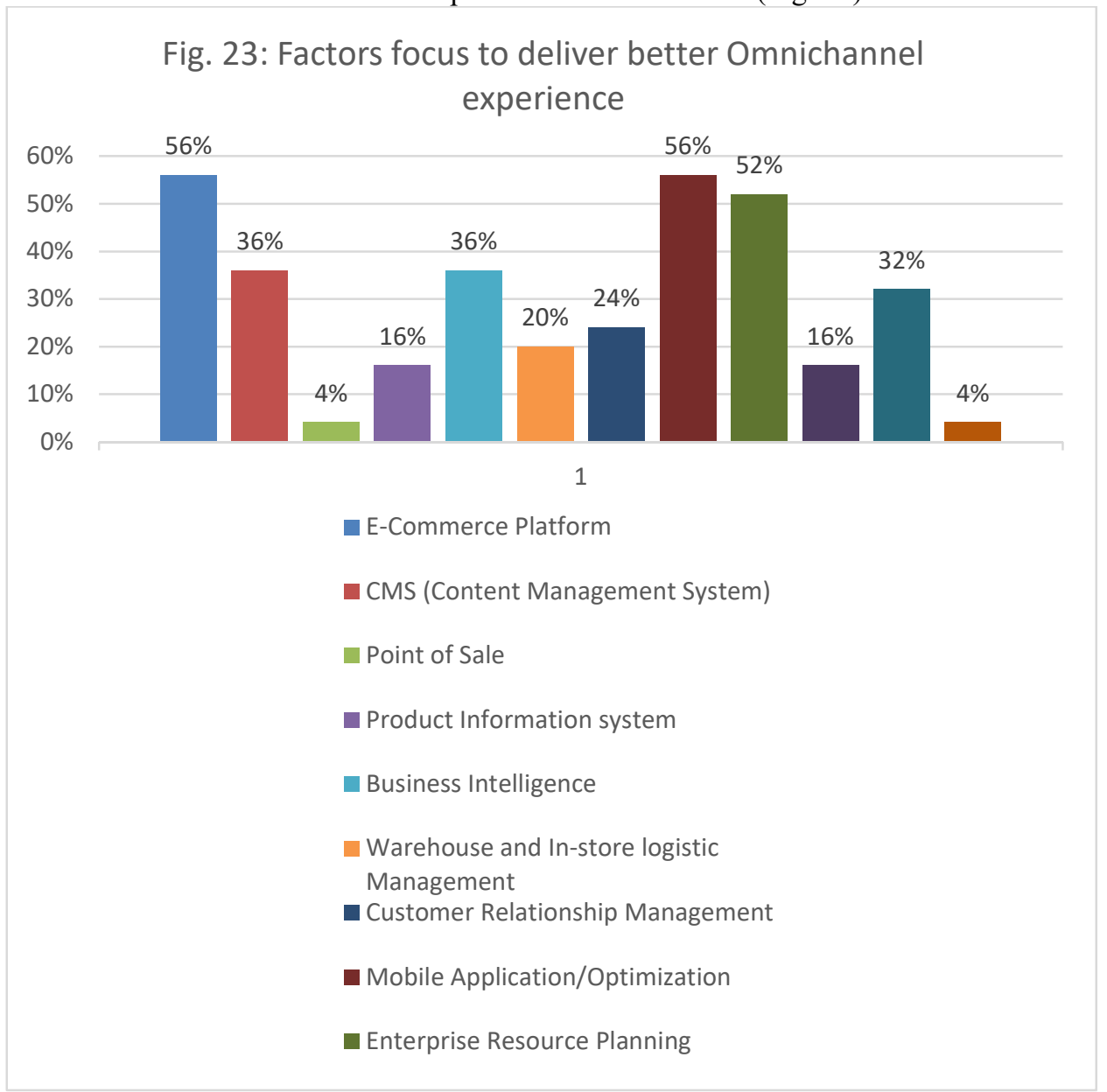

\subsubsection{SUMMERY OF POTENTIAL TOWARDS OMNICHANNEL RETAILING}

By the results of the survey, we can relate that there is still need lots of effort to improve businesses to provide omnichannel experience also need to work on internal management of the organization and focusing on to give training to the employees as per omnichannel business models, it would help in transforming their businesses.

Data and analytics has huge importance in omnichannel journey and this is the weaker side for the retailers of Pakistani Fashion Industries, so it needs to be emphasize more, Also need modification and change in IT to enhance omnichannel experience for the customer, Pakistani Fashion retailer focusing on to create profitability rather than to build loyalty for the customer and this is the main reason that in majority areas they are not 
compatible enough to provide full omnichannel experience but they are keep improving with time and focusing on to adopt those parameter which seems fit to accumulate their profitability with customer loyalty.

\section{CONSUMER PERSPECTIVE}

\subsection{METHODOLOGY}

\subsubsection{Data Collection:}

We used qualitative research in a structured questionnaire form including 23 indicators related with 7 independent and 1 dependent variables to know the opinion of shopper related with using omnichannel, and their purchase intention for acquiring it

\subsubsection{Sampling Size and Population:}

In Karachi, we targeting on those shoppers who are using more than one channel from same or the different retailers, total 224 respondents we examine but reduced sample size to 205 due to model fitness for our survey in which more than 172 are females and rest are the male respondents.

\subsubsection{Measurement/Instrument:}

We used scaling range from Strongly agree to strongly disagree to evaluate questions related with our topics variable

\subsubsection{Methodology for Data Analysis}

We used SPSS for Descriptive Statistics, Reliability Statistics and analysis and Amos 22 for CFA and SEM analysis to test our responses data, due to some error ${ }^{1}$ and Model fitness reliability factor we eliminated some of our responses and reduced the sample size to 205.

\subsection{DATA ANALYSIS:}

\subsubsection{Descriptive Statistic}

The table below showed the minimum values, maximum values, sum, mean and values of the standard deviation of all variables. The number of observations for each variable is 224 . All mean values show the central tendencies of each variable. Standard deviation values, minimum and maximum, show the dispersion of values from their mean. There description is as followed

\begin{tabular}{|c|c|c|c|}
\hline Variables & Item Label & Mean & $\begin{array}{c}\text { Std. } \\
\text { Deviation }\end{array}$ \\
\hline \multirow{3}{*}{$\begin{array}{l}\text { Hedonic } \\
\text { Motivation }\end{array}$} & $\begin{array}{l}\text { Q 3) Is it pleasurable to use more than one channel to purchase a } \\
\text { product? }\end{array}$ & 2.77 & 1.171 \\
\hline & $\begin{array}{l}\text { Q 2) Is it enjoyable to use Omnichannel Experience (using more } \\
\text { than one channel to purchase product)? }\end{array}$ & 2.18 & 0.688 \\
\hline & $\begin{array}{l}\text { Q 1) Do you think searching for a product online and buying it } \\
\text { on-store is an interesting experience? }\end{array}$ & 2.73 & 0.831 \\
\hline \multirow{3}{*}{$\begin{array}{l}\text { Performance } \\
\text { Expectancy }\end{array}$} & $\begin{array}{l}\text { Q 5) Is it useful to experience more than one Channel to purchase } \\
\text { Product? }\end{array}$ & 2.66 & 0.799 \\
\hline & Q 4) Do you think Omnichannel makes your life easier? & 2.16 & 0.738 \\
\hline & Q 6) Would Omnichannel influence your purchasing decision? & 1.79 & 0.611 \\
\hline \multirow{2}{*}{$\begin{array}{c}\text { Effort } \\
\text { Expectancy }\end{array}$} & $\begin{array}{l}\text { Q 7) Do you think that retailer's mobile apps are easy to use for } \\
\text { you? }\end{array}$ & 2.59 & 1.068 \\
\hline & $\begin{array}{l}\text { Q 8) Are you Flexible to learn different online platform for } \\
\text { Purchasing products? }\end{array}$ & 2.08 & 0.875 \\
\hline \multirow{4}{*}{$\begin{array}{c}\text { Social } \\
\text { Influence: }\end{array}$} & $\begin{array}{l}\text { Q 9) For purchasing I influence by the people who are important } \\
\text { to me to choose different channel and choosing whichever is most } \\
\text { convenient at given time }\end{array}$ & 2.96 & 0.872 \\
\hline & $\begin{array}{l}\text { Q 10) For purchasing I influence by the people who influence my } \\
\text { behavior to choose different channel and choosing whichever is } \\
\text { most convenient at given time }\end{array}$ & 2.1 & 0.873 \\
\hline & $\begin{array}{l}\text { Q 11) For purchasing I influence by the people whose } \\
\text { opinion/value prefer to choose different channel and choosing } \\
\text { whichever is most convenient at given time }\end{array}$ & 2.53 & 1.046 \\
\hline & $\begin{array}{l}\text { Q 12) For purchasing I influence by the people whose } \\
\text { opinion/value used to choose different channel and choosing } \\
\text { whichever is most convenient at given time }\end{array}$ & 2.35 & 0.603 \\
\hline
\end{tabular}

\footnotetext{
${ }^{1}$ Respondents provide intentionally or unintentionally an inaccurate answer.
} 


\begin{tabular}{|c|c|c|c|}
\hline Variables & Item Label & Mean & $\begin{array}{c}\text { Std. } \\
\text { Deviation }\end{array}$ \\
\hline \multirow{2}{*}{ Habits } & $\begin{array}{l}\text { Q 13) Do you have a habit to use different channels while } \\
\text { purchasing products? }\end{array}$ & 3.12 & 1.145 \\
\hline & $\begin{array}{l}\text { Q 14) Do you used frequently different channels for purchasing } \\
\text { a product? }\end{array}$ & 2.38 & 1.406 \\
\hline \multirow{3}{*}{ Security: } & $\begin{array}{l}\text { Q 15) Do you think it's safe to share your personal information } \\
\text { with retailers? }\end{array}$ & 2.3 & 0.617 \\
\hline & $\begin{array}{l}\text { Q 16) Are you comfortable using credit cards to make purchase } \\
\text { over internet? }\end{array}$ & 2.14 & 0.694 \\
\hline & Q 17) Do you think online transactions is safe? & 1.96 & 0.841 \\
\hline \multirow{3}{*}{$\begin{array}{l}\text { Personal } \\
\text { Innovativeness }\end{array}$} & Q 18) Are you like to acquiring new technologies? & 2.5 & 1.02 \\
\hline & $\begin{array}{l}\text { Q 19) Do you prefer to take an opinion for testing new product } \\
\text { from those who have already tried it? }\end{array}$ & 2.56 & 0.749 \\
\hline & $\begin{array}{l}\text { Q 20) Do you think you are innovative in term of acquiring new } \\
\text { technologies? }\end{array}$ & 1.79 & 0.618 \\
\hline \multirow{3}{*}{$\begin{array}{l}\text { Purchase } \\
\text { Intention }\end{array}$} & $\begin{array}{l}\text { Q 21) Would you like to purchase product from Omni channel } \\
\text { stores? }\end{array}$ & 3.29 & 0.838 \\
\hline & $\begin{array}{l}\text { Q 22) Would you suggest your colleagues/friends to experience } \\
\text { the omnichannel store? }\end{array}$ & 2.49 & 1.136 \\
\hline & $\begin{array}{l}\text { Q 23) Would you likely to switch on to omnichannel store } \\
\text { experience? }\end{array}$ & 2.89 & 1.262 \\
\hline
\end{tabular}

\section{Hedonic Motivation}

For survey questions related with hedonic motivation, more than $60 \%$ voted disagree for omnichannel as a pleasurable or enjoyable experience, also just $28 \%$ believe that it would be an interesting experience as per interrogation we found they believe that it would be make their shopping experience more complicated.

\section{Performance Expectancy}

In performance expectancy $65 \%$ agreed and strongly agreed that it's influence their purchasing decision but only $32 \%$ believe or agreed that it makes their life easier, however the ratio of experience more than one channel to purchase product is useful was $57 \%$ in our survey report.

\section{Effort Expectancy}

The ration of agree was found 34\% however dis agree 32\% related with flexibility of learning different online platform for purchasing the product, also $43 \%$ voted retailers mobile apps are easy to use for them and $30 \%$ not willing to answer the question.

\section{Social Influence}

Social influence not found as much good and supported for omnichannel in our survey and just 36\% found agreed who are doing shopping by influencing someone or someone decision or prefer someone else decision to purchasing the product.

\section{Habits}

We targeted those who are using more than one channel in our survey and the result we found in habit predictor is much more supported for omnichannel journey $94 \%$ are those who are using different channels while purchasing the product and $82 \%$ agreed and strongly agreed to use frequently different channel for purchasing the product.

\section{Security}

Security not found to be that much supported or positively influence in Pakistan as per our survey we found only $18 \%$ agreed to share their personal information with the retailers and $27 \%$ believe that online transaction is safe also $39 \%$ comfortable using credit cards to make purchase over internet.

\section{Personal Innovativeness}

Personal innovativeness also found as a good predictor for omnichannel journey more than $52 \%$ like to acquiring new technologies also $72 \%$ believe to take an opinion for testing new product from those who have already tried it, and $40 \%$ people think that they are innovative in terms of acquiring new technologies.

\section{Purchase Intention}

The survey results show that more than $50 \%$ people like to experience omnichannel store to purchase and they will suggest their colleagues and friends if they get the good experience also $45 \%$ agreed to switch on to omnichannel store if they get good experience from it. 
INFERENTIAL STATISTICS

5.5.2 RELIABILITY ANALYSIS

Table 5: Reliability Scores $(\mathbf{N}=\mathbf{2 0 5})$

\begin{tabular}{|c|c|c|}
\hline Variables & No of Items & Cronbach's Alpha \\
\hline Hedonic Motivation & 3 & 0.792 \\
\hline Social Influence & 4 & 0.767 \\
\hline Habit & 2 & 0.985 \\
\hline Personal Innovativeness & 3 & 0.782 \\
\hline Effort Expectancy & 2 & 0.842 \\
\hline Performance Expectancy & 3 & 0.710 \\
\hline Purchase Intention & 3 & 0.820 \\
\hline Security & 3 & 0.825 \\
\hline
\end{tabular}

Table 6. Reliability Statistic

\begin{tabular}{|l|l|}
\hline Cronbach's Alpha & N of Items \\
\hline .820 & 23 \\
\hline
\end{tabular}

Reliability test was done to assess the significance of data (J. Nunnally, 1978; J. C. Nunnally \& Bernstein, 1994). In above table the values of reliability test show acceptable results with all items included. The value of Cronbach alpha for emotion of love in advertisement is 0.7 . The reliability of all the variables including dependent and independent variables is greater than the cut off value that is 0.70 which was good (Santos, 1999). Overall Cronbach's Alpha of the questionnaire was 0.820 . Which is significant as it is greater than the cut off value which is 0.7 . Besides purchase intention indicates 0.82 reliability which is also acceptable as it falls between the standard ranges of 0.5-0.9. Research instrument used in this study measure different aspects of Emotional Advertisement as love, humor, happiness and excitement appeal which may Home appliance brands in influencing customer buying behavior.

\subsubsection{CONFIRMATORY FACTOR ANALYSIS USING AMOS}

Many Different things need to be checked for the data appropriation for testing the model to make sure it is clearly represented the sufficient number and it is important to look variable-to-factor ration (Preacher \& MacCallum, 2002). It's Important to atleast three items for each factors (Anderson \& Rubin, 1956), else it would be weak. However, most often contain one such factor also acceptable (Costello \& Osborne, 2005). Confirmatory factor analysis was performed using AMOS 25. Factor analysis was employed to reduce large number of variables to extract most underlying variables called factor. Confirmatory factor analysis is a useful method to examine the variability among observed variables and excerpt variability from items and load them into a common factor. As the study entails exploratory nature, factor analysis was done to identify the most important construct, i.e. Emotion of Love, Humor, Happiness, Excitement and buying behavior. 


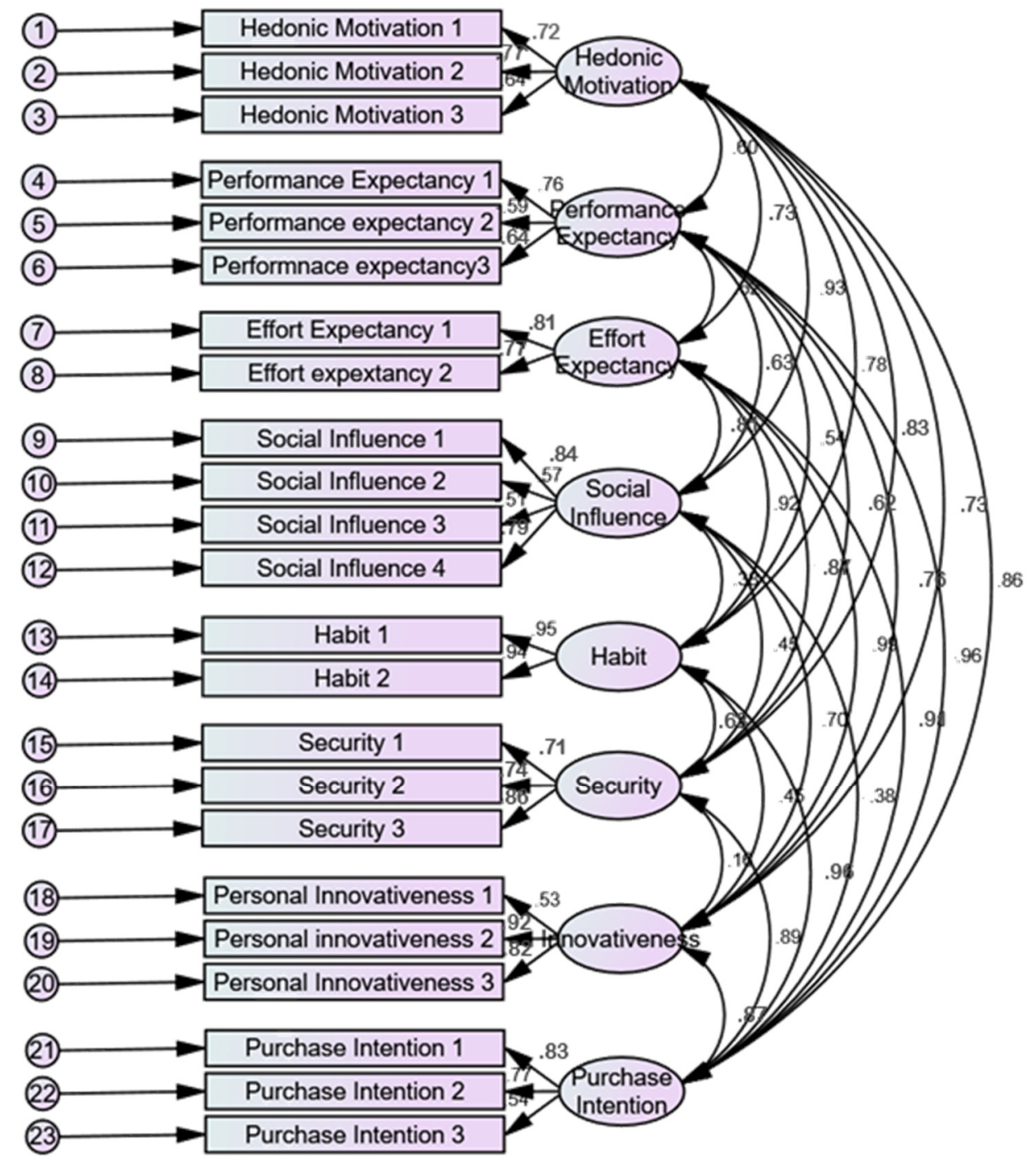

Figure 24: Confirmatory Factor Analysis Using Amos 25

Table 7: Standardized Regression Weights

\begin{tabular}{|c|c|l|c|}
\hline Latent Variable & $\begin{array}{l}\text { Item } \\
\text { Label }\end{array}$ & \multicolumn{1}{|c|}{ Item Description } & $\begin{array}{c}\text { Standardized Factor } \\
\text { Loading }\end{array}$ \\
\hline Hedonic Motivation & Q1 & Omnichannel is an interesting experience & 0.72 \\
\hline Hedonic Motivation & Q2 & Omnichannel is enjoyable experience & 0.77 \\
\hline Hedonic Motivation & Q3 & Using more than one channel is enjoyable & 0.64 \\
\hline $\begin{array}{c}\text { Performance } \\
\text { Expectancy }\end{array}$ & Q4 & Omnichannel makes life Easier & 0.76 \\
\hline $\begin{array}{c}\text { Performance } \\
\text { Expectancy }\end{array}$ & Q5 & Experience more than one channel is useful & 0.59 \\
\hline $\begin{array}{c}\text { Performance } \\
\text { Expectancy }\end{array}$ & Q6 & Omnichannel influence your purchasing & 0.64 \\
\hline Effort Expectancy & Q7 & Retailers mobile apps are easy to use & 0.81 \\
\hline Effort Expectancy & Q8 & Flexible to learn different platform & 0.77 \\
\hline $\begin{array}{c}\text { Social Influence } \\
\text { Q9 }\end{array}$ & $\begin{array}{l}\text { Influence who are important to me to use different } \\
\text { channel for purchasing }\end{array}$ & 0.84 \\
\hline Social Influence & Q10 & $\begin{array}{l}\text { Influence the behavior to use different channel for } \\
\text { purchasing }\end{array}$ & 0.57 \\
\hline Social Influence & Q11 & $\begin{array}{l}\text { influence by those whose opinion/value prefer to } \\
\text { choose different channel }\end{array}$ & 0.51 \\
\hline
\end{tabular}




\begin{tabular}{|c|c|c|c|}
\hline Latent Variable & $\begin{array}{l}\text { Item } \\
\text { Label }\end{array}$ & Item Description & $\begin{array}{l}\text { Standardized Factor } \\
\text { Loading }\end{array}$ \\
\hline Social Influence & Q12 & $\begin{array}{l}\text { influence by those whose opinion/value used to } \\
\text { choose different channel }\end{array}$ & 0.79 \\
\hline Habit & Q13 & Habit to choose different Channel & 0.95 \\
\hline Habit & Q14 & Frequently use different channel & 0.94 \\
\hline Security & Q15 & Safe to share the personal information & 0.71 \\
\hline Security & Q16 & Comfortable to use credit card for purchase & 0.74 \\
\hline Security & Q17 & Online Transaction is safe and secure & 0.86 \\
\hline $\begin{array}{c}\text { Personal } \\
\text { Innovativeness }\end{array}$ & Q18 & Likely to acquiring new Technologies & 0.53 \\
\hline $\begin{array}{c}\text { Personal } \\
\text { Innovativeness }\end{array}$ & Q19 & $\begin{array}{l}\text { Prefer to take opinion for the product from those } \\
\text { who tried it earlier }\end{array}$ & 0.92 \\
\hline $\begin{array}{c}\text { Personal } \\
\text { Innovativeness }\end{array}$ & Q20 & Innovative to acquiring new technologies & 0.82 \\
\hline Purchase Intention & Q21 & Like to purchase product from omnichannel & 0.83 \\
\hline Purchase Intention & Q22 & $\begin{array}{l}\text { Suggest colleagues/Friends to experience } \\
\text { omnichannel }\end{array}$ & 0.77 \\
\hline Purchase Intention & Q23 & Like to switch on omnichannel store experience & 0.54 \\
\hline
\end{tabular}

The above table shows Standardized factor loading for each item and shows the association between individual items with the extract construct. Factor loading for each item depicts reasonable to strong relationship with the underlying construct.

\subsubsection{EVALUATING MEASUREMENT MODEL FITNESS}

To evaluate the fitness of the proposed model, Amos delivers a set of useful indices that are used to determine the fitness and validity of the hypothesized model. Out of different significant indices, root mean square error of approximation (RMSEA), goodness of fit index (GFI), Chi-Square, CMIN/DF, adjusted goodness of fit index (AGFI), and comparative fit indices were observed to determine the authenticity of the research model. The discussed indices show the degree to which constructs are related to one another. Table no 8 and figure 24 demonstrate the resultant values.

Table 8: Model Fitness Test

\begin{tabular}{|c|c|c|}
\hline Model Fit & Resultant Value & Threshold \\
\hline CMIN/DF & 2.498 & $<3$ good ; <5 Acceptable \\
\hline CFI & 0.928 & Closer to 1; good \\
\hline GFI & 0.936 & $>0.90$ \\
\hline AGFI & 0.906 & $>0.90$ \\
\hline RMR & 0.056 & $<0.08$ \\
\hline RMSEA & 0.065 & $<0.08$ \\
\hline
\end{tabular}

The measured values of CMIN/DF, CFI, PCLOSE GFI, RMR, and RMSEA meet the threshold and shows an acceptable model fit. However, the values of AGFI slightly differs from the standard values.

\subsubsection{STRUCTURAL EQUATION MODELING}

Structural equation modeling used to evaluate the structural relationship between exogenous and endogenous variables. The structural equation modeling includes factor analysis and multivariate analysis of the model. Firstly, we evaluate the model fitness and measure whether the paths showing the relationship between measured and latent variables are significant or not. The path diagram showed in figure 25. In this diagram Performance Expectancy, Effort Expectancy, Social Influence, Hedonic Motivation, Habit, Personal Innovativeness and Security towards customer Purchase Intention. Besides table 9 shows the model fit results by analyzing model fit indices. 


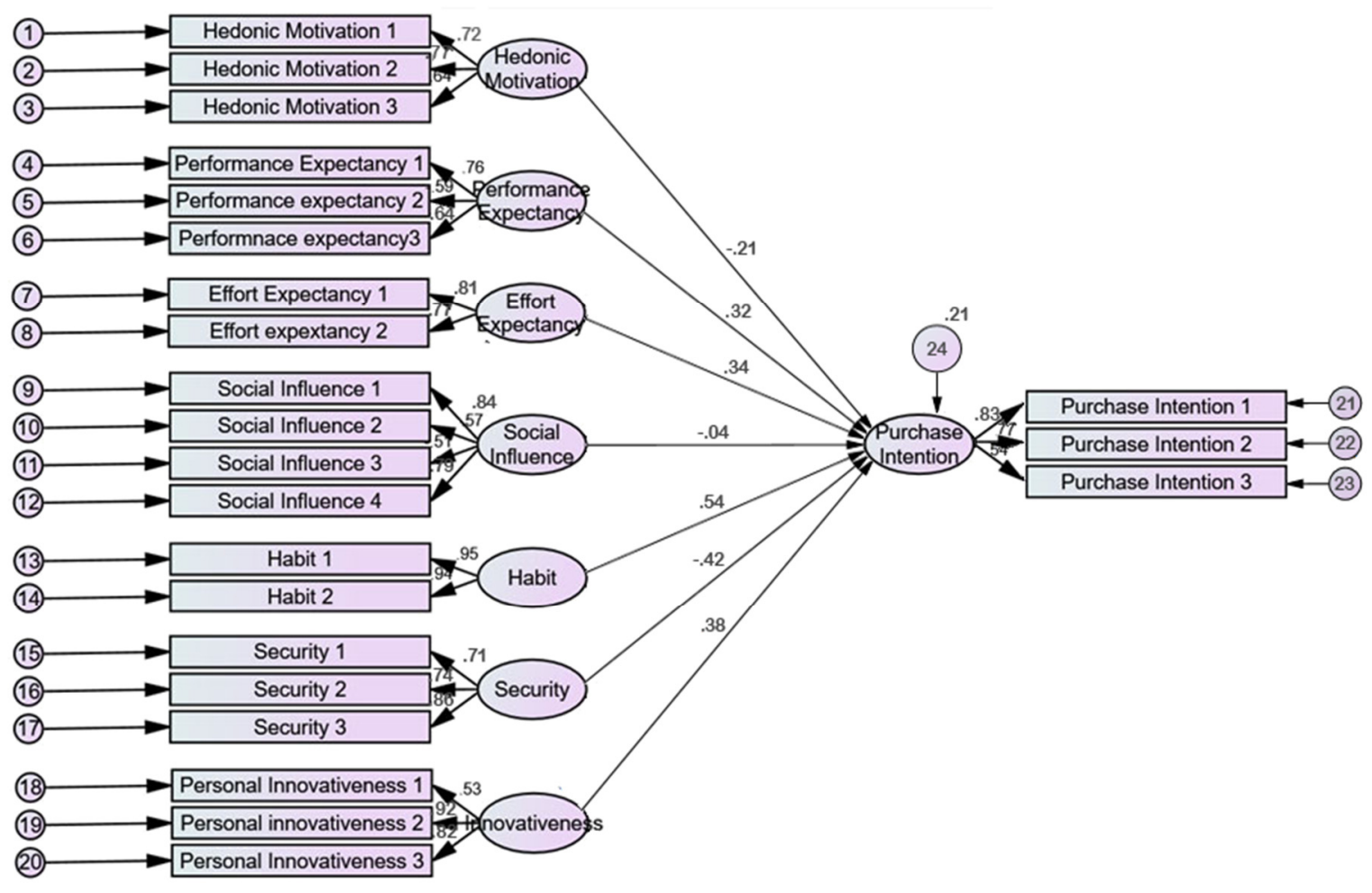

Figure 25: Path Diagram

\subsubsection{EVALUATING MEASUREMENT MODEL FITNESS}

To evaluate the fitness of the proposed model, Amos delivers a set of useful indices that are used to determine the fitness and validity of the hypothesized model. Out of different significant indices, root mean square error of approximation (RMSEA), goodness of fit index (GFI), Chi-Square, CMIN/DF, adjusted goodness of fit index (AGFI), and comparative fit indices were observed to determine the authenticity of the research model. The discussed indices show the degree to which constructs are related to one another. Table no 8 and figure 25 demonstrate the resultant values.

Table 9: Model Fitness Test

\begin{tabular}{|c|c|c|}
\hline Model Fit & Resultant Value & Threshold \\
\hline CMIN/DF & 2.356 & $<3$ good $;<5$ Acceptable \\
\hline CFI & 0.928 & Closer to $1 ;$ good \\
\hline GFI & 0.936 & $>0.90$ \\
\hline AGFI & 0.906 & $>0.90$ \\
\hline RMR & 0.052 & $<0.08$ \\
\hline RMSEA & 0.062 & $<0.08$ \\
\hline
\end{tabular}

There are different parameters to evaluate the goodness of a fit model. The study has adopted seven model fit indices to predict model fitness. Performance Expectancy, Effort Expectancy, Social Influence, Hedonic Motivation, Habit, Personal Innovativeness and Security were measured through 7 items and these were designed to measure Purchase intention for omnichannel journey. The results of structural equation modelling depict a good fit. Comparative fit index (CFI) point up a good fit value of 0.82 by meeting the standard value, with adjusted goodness of fit index (AGFI) at 0.92 by being perfect for the threshold of 0.90 , the root mean square error of approximation (RMSEA) is 0.062 and signifies consistency of our data and a good fit.

The calculated value of CMIN/DFI is 2.356 which shows a good model fit. The values of CFI, RMSEA, specifies that the proposed model was statistically fit as these parameters resultant values meets threshold as explained in the table 9 . 
Table 10: Regression Weights (Hypothesis Testing)

\begin{tabular}{|lll|l|l|l|l|l|}
\hline & & & Estimate & SE & CR & P & \\
\hline Purchase_Intention & $<---$ & Performance_Expectancy & 0.321 & 0.071 & 3.049 & 0.000 & H1 Accepted \\
\hline Purchase_Intention & $<---$ & Effort_Expectancy & 0.343 & 0.04 & 16.11 & 0.000 & H2 Accepted \\
\hline Purchase_Intention & $<---$ & Social_Influence & -0.041 & 0.185 & 0.329 & 0.74 & H3 Rejected \\
\hline Purchase_Intention & $<---$ & Hedonic_Motivation & -0.212 & 0.121 & -1.75 & 0.079 & H4 Rejected \\
\hline Purchase_Intention & $<---$ & Habit & 0.542 & 0.022 & 25.07 & 0.000 & H5 Accepted \\
\hline Purchase_Intention & $<---$ & Personal_Innovativeness & 0.38 & 0.001 & 7.158 & 0.000 & H6 Accepted \\
\hline Purchase_Intention & $<---$ & Security & -0.425 & 0.174 & -9.76 & 0.42 & H7 Rejected \\
\hline
\end{tabular}

The above table illustrate the influence of Performance Expectancy, Effort Expectancy, Social Influence, Hedonic Motivation, Habit, Personal Innovativeness and Security predictors on Purchase Intention for Omnichannel Development with in Pakistani Fashion Retail. Each independent predictor gives an unstandardized and standardized beta coefficient that predicts the positive or negative impact of each variable. While $p$-value measures significance of data at $95 \%$ confidence interval.

First, 'Performance Expectancy' has a Positively influence on 'Purchase Intention' $(\beta=0.32, p<.001)$, therefore H1 is accepted. Second, 'Effort Expectancy' also has a Positively influence on 'Purchase Intention', $(\beta$ $=0.34, \mathrm{p}<.001)$, therefore H2 is accepted. Third, 'Social Influence' has no Positively influence on 'Purchase Intention", $(\beta=-0.04, p>.001)$, therefore H3 is rejected

Fourth, 'Hedonic Motivation' also not Positively influence on 'Purchase Intention' $(\beta=-0.21, p>.001)$, therefore H4 is also rejected. Fifth 'Habit' Found a significant Positive influence on 'Purchase Intention' $(\beta=$ $0.542, \mathrm{p}<.001)$, therefore H5 is accepted. Sixth 'Personal Innovativeness' also found positive influence on 'Purchase Intention' $(\beta=0.38, \mathrm{p}<.001)$, therefore H6 is also accepted. Last 'Security' not Found a Positive impact on 'Purchase Intention' $(\beta=-0.42, p>.001)$, therefore H5 is accepted.

\section{Discussions}

\subsection{Retailer's perspective}

In our selected samples of retailers, we mainly focused which parameter of development index is already done yet not at which stage the tested parameters are, also it is time consuming procedure if we going to check all the parameters stages.

The main points highlighted are as followed

1. Consumer raise concerns about the relevance of information, store locations, business hours, available inventory etc. Kwon and Jane, (2009) have also mentioned consumers are unaware of the inventory and direction for stores location. Thus consumer do not able to visit stores due to incomplete data on retailers site.

2. Consumers express dissatisfaction in business transformation to confront their personal needs dynamics. As supported in (Tetteh and $\mathrm{Xu}$ ), retailers need to provide timely updates, moreover these updates would meet the consumer demands so it would be in a result in Profit maximization for retailers.

3. Across all the channels retailers should be consistent in the messages that reaches to the consumer, moreover this must have an equal feel in all their channel. Baxendale, Macdonald, and Wilson, (2015) sustain that the firms that develop Omni-channel marketing should certain that the strategy adds more value to the consumer.

4. All consumers must get easily access to omnichannel shopping experience without any concern of their geographic location, retailers must certain that omnichannel experience would not be intrusive for the consumer and it provides customer all relevant information which they want to access, data and analytics factors would need to be strongest to provide customer seamless shopping experience.

5. Also Omnichannel must not disregard security concerns for the customer to offered their personal information to the retailers, the consumer must have enough knowledge to understand the procedure of data collection, use of the provided data and offers that they would get after providing the data to the retailers. Retailers transparency is the most important in omnichannel shopping experience (Baxendale, Macdonald, and Wilson, 2015).

Use of omnichannel approach can be reasoned at creating more profit. Cao (2014). Thus omnichannel entails more capacity to reduce the costs and maximize returns. Retailers can be used omnichannel to bring new services and making it easier for the consumer to access it, also the customization of marketing effort would be easy for the consumer to acquire, Fernández-Sabiote and Román, (2015) states that firm should take proactive approach to learning from their mistake and use initiative for their long term support. Moreover, a future strategy for the retailers would be to change their management structure with keep consideration of new innovation, the retailers and the consumer also needs to be managed by increasing the trust in the marketing initiative, and retailers deliver consumers better deal than before Picot-Coupey, Huré \& Piveteau, (2015) to get their loyalty and long terms 
benefits from the consumer.

\subsection{Consumer Perspective}

In Consumer perspective the main target is to check the predictors which would be supportive in technology acceptance and use among omnichannel consumer, we examine Unified Theory of Acceptance and Use of Technology (UTAUT 2) model (Venkatesh et al., 2012) with additional predictor of Personal Innovativeness and Security which found important for adaptation of technology in some literature on consumer behavior (e.g., Salisbury et al., 2001; Herrero and Rodriguez del Bosque, 2008; Escobar-Rodríguez and Carvajal-Trujillo, 2014; Frasquet et al., 2015). The model was design to predict purchase intention for omnichannel and we found that Performance expectancy, Effort expectancy, Habit and Personal innovativeness positively influence the purchase intention although Perceived Security, Hedonic Motivation and Social influence do not effect positively on purchase intention.

As per our Model analysis we found Habit is the strongest predictor for omnichannel purchase intention which contradict some previous litreture who took habit as moderate predictor for purchase intention (Venkatesh, 2012; Ji \& Wood, 2007; Juaneda-Ayensa et al., 2016; Agag \& El-Masry (2016). Personal Innovativeness found as second strongest indicator which is consistent in finding for some previous literature (e.g., Herrero and Rodriguez del Bosque, 2008; Lu et al., 2011; San Martín and Herrero, 2012; Escobar-Rodríguez and Carvajal-Trujillo, 2014) also Performance and Effort Expectancy found as positively influence and has been reported in previous literature (e.g., Childers et al., 2001; Verhoef et al., 2007; Rose et al., 2012).

In Contrast Social Influence, Hedonic Motivation and Perceived Security not found to give positive influence on purchase intention, Social Influence results found contrast for some previous research (Venkatesh et al., 2012; Escobar-Rodríguez; Kim et al., 2009; and Carvajal-Trujillo, 2014). The reason would be the different mind frame related with technology for different people which influence in their opinion so may be it would need to study more in depth further, also hedonic motivation contradict the analysis result of some previous study (e.g., Thong et al., 2006; Venkatesh et al., 2012; Escobar-Rodríguez and Carvajal-Trujillo, 2014). This is may be the reason of the technology acceptance is much more related with Personal Innovativeness rather than hedonic and utilitarian motivation and the perceived security results support the previous theory (e.g. Kim et al., 2008; Yenisey et al., 2005; Fortes \& Ritas, 2016) but found contradict with some theories (e.g., Salisbury et al., 2001; Frasquet et al., 2015). The main reason we found in our analysis is online transaction and payments system which seems threaten for the shoppers in Pakistan and look as a barrier for omnichannel but retailer can encounter this problem by offering traditional In-store Payment or by using payment options at the time of home delivery, thus all the predictors that we examine on purchase intentions are based on our targeted population and it may be differ on others scenario also the consideration of measurement error (4.5) would be the reason for affected the final results.

\subsection{Combined Perspective}

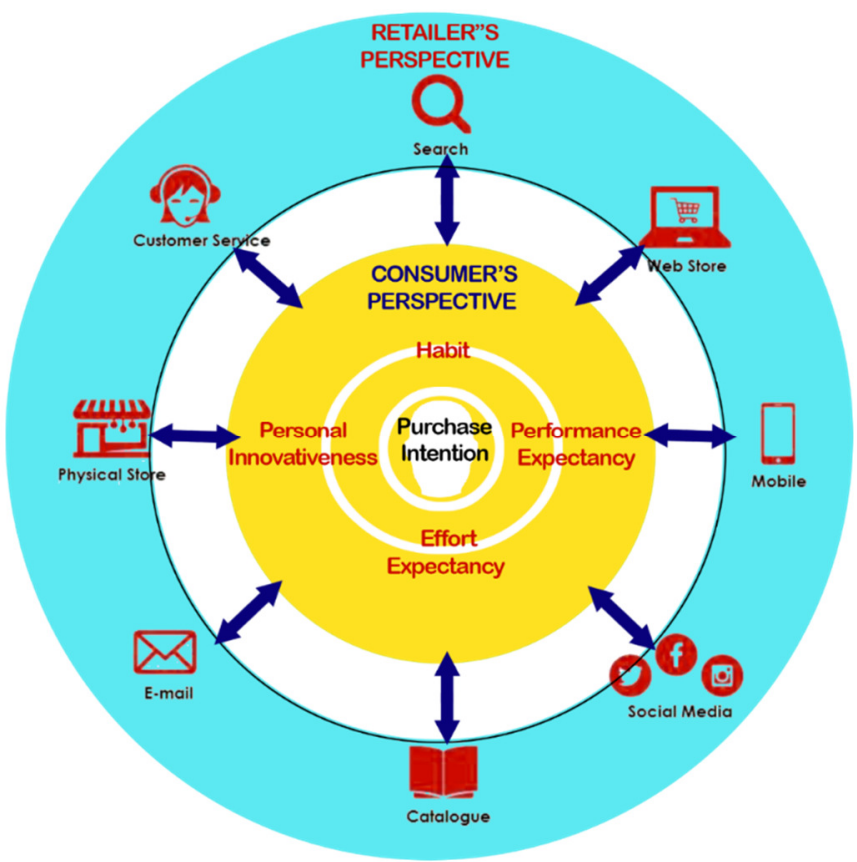

Fig 26: Combine retailers and consumer perspective model for omnichannel Development Source:(Own Illustration). 
As per our analysis for both retailer and consumer perspective, a model (Fig. 26) is developed for omnichannel success in Pakistani Fashion retail industry, however this model would be recommended for all Fashion retail industry around the world. By summing up all the data from retailers and consumer side we recommend that retailers should integrate their all channels in a way that it Facilitate all the related predictors (Performance Expectancy, Effort Expectancy, Habit and Personal Innovativeness) of the consumer which influence their purchase intention, Consumer demands for more these days and technology make them more knowledgeable which is somehow increase their negotiation power, also technology increases the competition twice in a very short time and many retailers are wipe out from the market just because of ignoring the fact of integrating the new technology and customers' needs to meet their demands, retailers need to accept the reality of changing buying behavior of the consumer also the expectation of new generation for their business if they want to compete in digital era, the observed predictors in a model will help them out to understand consumer buying behavior more and to improve their efficiency for the consumer by integrating all of their channels to facilitate it for deliver better omnichannel experience to them.

\section{CONCLUSION}

Pakistan seen as in very early stages of omnichannel development, Fashion Retailers are transforming their business but this journey seems more difficult and complex for the retailers, the field study parameters results indicates that there is much need to developed all five categories from initial to moderate and then advance level to give unified experience to the customer, also Lack of digital maturity and internal organization behavior seems as biggest challenge for the retailers although some for-profit organizations believed that it would be increased their cost.

More than $50 \%$ retailers seen agreed in terms of acquiring omnichannel and willing to substantial reengineering in their business modules and modify their front-ends and back ends operations to give consumer unified seamless experience in their shopping journey from different channels but they need to focus more on their Data and analytics factors and rectify the barrier of their security concern related with providing their personal information to the retailers also From Our digital survey we found that retailers need to make their online platform more convenient for the shopper and give Loyalty programs in a way to provide consumer ease in their shopping experience to use more retailers channel when they shop.

Fashion Businesses are transforming from offline channels to multi-channels but it's just a start and retailers need lots of effort to understand consumer shopping behavior and the factors which influence their purchase intentions, we proposed a model (Fig. 26) after summing up all of the results of both consumer and retailer perspective related with omnichannel success in Pakistani Fashion retail and found some main predictors (Habit, Personal Innovativeness, Performance expectance and Effort expectancy) which will drive purchase intentions of the consumer and retailer should focusing those predictors, to gain long-term benefits in such a competitive landscape of fashion retail in Pakistan.

Omnichannel will be benefits for both consumer and retailers, as we are living in a digital era where technology improves every day and it changes the shopper behavior and the way they like to do shopping, consumer are advanced these days and more demanding in terms of facilitation in their shopping experience from retailers also for retailers it's difficult to survive in such a competitive landscape without any new features through which they are able to provide more satisfaction to the consumer in their shopping experience and omnichannel success will give long-term benefits to both, For retailers in the form of customer loyalty which would be a competitive advantage for them and for consumer, facilitation and ease in their shopping experience, Retailers agreement are important for omnichannel success and they need to work on all their mentioned parameters equally to provide a consumer unified and seamless shopping experience and developed a perfect omnichannel within Pakistani Fashion Retails.

\subsection{RECOMMENDATIONS:}

It is recommended that all Fashion Retailers of Pakistan should focus to transform their business modules and modify their Data \& analytics factors to raise Omnichannel journey in Pakistan also it is essential to work on Loyalty services as it seen unfocused, and need other parameters category to enhance omnichannel experience for customer. Security is found the biggest threat and barrier to developed omnichannel services in Pakistan, which is responsibility of Govt. and security forces to make it better and retailers should integrate all of their channel and provide ease online Platform for the customer to improve effort expectancy indicator which helps in more boost of omnichannel in Pakistan.

\section{REFERENCES}

Aarts, H., Verplanken, B., \& Knippenberg, A. (1998). Predicting behavior from actions in the past: Repeated decision making or a matter of habit? Journal of Applied Social Psychology, 28(15), 1355-1374.

Accenture. (2016). Retail customers are shouting - are you adapting? 
https://www.accenture.com/ acnmedia/PDF-7/Accenture-Adaptive-Retail-Research-Executive-Summary$V 2 . p d f$

Agag, G., \& El-Masry, A. A. (2016). Understanding the determinants of hotel booking intentions and moderating role of habit. International Journal of Hospitality Management, 54, 52-67.

Agarwal, R., \& Prasad, J. (1998). A conceptual and operational definition of personal innovativeness in the domain of information technology. Information systems research, 9(2), 204-215.

Agatz, N., Fleischmann, M. \& van Nunen, J. (2008). E-fulfillment and multi-channel distribution - A review. European Journal of Operational Research, 187(2), 339-356.

Anderson, T. W., \& Rubin, H. (1956). Statistical inference in factor analysis. In J. Neyman (Ed.), Proceedings of the Third Berkeley Symposium on Mathematical Statistics and Probability (pp. 111-150). Berkeley, CA: University of California Press.

Avensia, 2015. Omni-Channel Retail 2015: A Scandinavian Omni-channel Index,

Babin, B.J., Darden, W.R. and Griffin, M. (1994), "Work and/or fun: measuring hedonic and utilitarian shopping value", Journal of Consumer Research, Vol. 20 No. 4, pp. 644-56.

Baxendale, S., Macdonald, E. and Wilson, H. (2015). The Impact of Different Touchpoints on Brand Consideration. Journal of Retailing, 91(2), pp.235-253.

Bell, D., Gallino, S. and Moreno, A. (n.d.). Inventory Showrooms and Consumer Migration in an Omni-Channel Retail: The Effect of Product Information. SSRN Electronic Journal.

Brynjolfsson, E., Hu, Y. J., Rahman, M. S. (2013) Competing in the age of omnichannel retailing. MIT Sloan Management Review,54(4), 1-29.

Burgess, R.G., Candappa, M., Galloway, S. and Sanday, A. (1989) Energy Educationand the Curriculum, CEDAR, University of Warwick

Cao, L. (2014). Business Model Transformation in Moving to a Cross-Channel Retail Strategy: A Case Study. International Journal of Electronic Commerce, 18(4), pp.69-96.

Carvalho, and Compomar, (2014). MULTICHANNEL AT RETAIL AND OMNI-CHANNEL: Challenges for Marketing and Logistics. Production and Operations Management, 24(3), pp.360-362.

Cha, J. (2011). Exploring the Internet as a unique shopping channel to sell both real and virtual items: a comparison of factors affecting purchase intention and consumer characteristics. Journal of Electronic Commerce Research, 12(2), 115.

Chiu, C. M., Hsu, M. H., Lai, H., \& Chang, C. M. (2012). Re-examining the influence of trust on online repeat purchase intention: The moderating role of habit and its antecedents. Decision Support Systems, 53(4), 835845.

Childers T. L., Carr C. L., Peck J., Carson S. (2001). Hedonic and utilitarian motivations for online retail shopping behavior. J. Retail. 77, 511-535. 10.1016/S0022-4359(01)00056-2

Costello, A. B., \& Osborne, J. W. (2005). Best practices in exploratory factor analysis: Four recommendations for getting the most from your analysis. Practical Assessment Research \& Evaluation, 10(7)

Crittenden, V. L., Peterson, R. A., and Albaum, G. (2010). Technology and business-to-consumer selling: contemplating research and practice. J. Pers. Selling Sales Manag. 30, 103-110. doi:10.2753/PSS08853134300201

Davis, F. D. (1989). Perceived usefulness, perceived ease of use, and user acceptance. MIS Q. 13, 319-339. doi: $10.2307 / 249008$

Davis, F. D., Bagozzi, R. P., and Warshaw, P. R. (1989). User acceptance of computer technology: a comparison of two theoretical models. Manage. Sci. 35, 982-1003. doi : 10.1287/mnsc.35.8.982

Deloitte, 2015. Omni-channel retail: A Deloitte Point of View,

Escobar-Rodríguez, T., \& Carvajal-Trujillo, E. (2014). Online purchasing tickets for low cost carriers: an application of the unified theory of acceptance and use of technology (UTAUT) model. Tourism Manag. 43, 70-88.

Fernández-Sabiote, E. and Román, S. (2015). The multichannel consumer's service experience: building satisfaction and trust. Serv Bus, 10(2), pp.423-445.

Fishbein M., Ajzen I. (1975). Belief, Attitude, Intention, and Behavior: An Introduction to Theory and Research. Reading, MA: Addison-Wesley.

Fortes, N., \& Ritas, P. (2016). Privacy concerns and online purchasing behavior: towards an integrated model. European Research on Management and Business Economics, 22(3), 167-176.

Frasquet, M., Mollá, A., \& Ruiz, E. (2015). Identifying patterns in channel usage across the search, purchase and post-sales stages of shopping. Electron. Commer. Res. Appl. 14, 654-665.

Frazer, M. \& Stiehler, B. E. (2014). Omnichannel retailing: The merging of the online and offline environment. Global Conference on Business and Financial Proceedings, 9(1), 655- 657.

Galbraith, J. R. (2005). Designing the consumer-centric organization: A guide to strategy, structure, and process. San Francisco: Jossey-Bass. 
Grewal, D., Iyer, G. R. \& Levy, M. (2004). Internet retailing: enablers, limiters and market consequences. Journal of Business Research, 57(7), 703-713.

Gummesson, E. (2008). Consumer centricity: reality or a wild goose chase?", European Business Review, 20(4), $315-330$.

Herhausen, D., Binder, J., Schoegel, M. and Herrmann, A. (2015). Integrating Bricks with Clicks: Retailer-Level and Channel-Level Outcomes of Online-Offline Channel Integration. Journal of Retailing, 91(2), pp.309325.

Herrero, A., \& Rodriguez del Bosque, I. (2008). The effect of innovativeness on the adoption of B2C ecommerce: a model based on the Theory of Planned Behavior. Computer in Human Behavior. 24, 2830-2847.

Huang, C. Y., Kao, Y. S., Wu, M. J. and Tzeng, G. H. (2013, July) Deriving factors influencing the acceptance of Pad Phones by using the DNP based UTAUT2 framework.

In Technology Management in the IT-Driven Services (PICMET), 2013 Proceedings of PICMET'13: (pp. 880887). IEEE.

Ji, M. F., \& Wood, W. (2007). Purchase and consumption habits: Not necessarily what you intend. Journal of Consumer Psychology, 17(4), 261-276.

Juaneda-Ayensa, E., Mosquera, A., \& Murillo, Y. S. (2016). Omnichannel Customer Behavior: Key Drivers of Technology Acceptance and Use and Their Effects on Purchase Intention. Frontiers in Psychology, 7.

Kalyanam, K., \& Tsay, A. (2013). Free riding and conflict in hybrid shopping environments: Implications for retailers, manufacturers, and regulators. The antitrust bulletin, 58(1), 19-68.

Kang, M., Liew, B. Y. T., Lim, H., Jang, J. and Lee, S. (2015) Investigating the Determinants of Mobile Learning Acceptance in Korea Using UTAUT2. In Emerging Issues in Smart Learning (pp. 209-216). Springer, Berlin Heidelberg.

Khalifa, M., \& Liu, V. (2007). Online consumer retention: contingent effects of online shopping habit and online shopping experience. European Journal of Information Systems, 16(6), 780-792.

Kim, D. J., Ferrin, D. L. and Rao, H. R. (2008) A trust -based consumer decision-making model in electronic commerce: The role of trust, perceived risk, and their antecedents. Decision Support Systems, 44(2), 544564.

Kumar, V., and Raheja, G., 2012. BUSINESS TO BUSINESS (B2B) AND BUSINESS TO CONSUMER (B2C) MANAGEMENT. International Journal of Computers \& Technology Volume 3 No. 3, Nov-Dec, 2012

Kwon, K. and Jane, D. (2009). Multichannel Shopping Through Nontraditional Retail Formats: Variety-Seeking Behavior with Hedonic and Utilitarian Motivations. Journal of Marketing Channels, 16(2), pp.149-168.

Lu Y., Cao Y., Wang B., Yang S. (2011). A study on factors that affect users' behavioral intention to transfer usage from the offline to the online channel. Comput. Human Behav. 27, 355-364. 10.1016/j.chb.2010.08.013

MasterCard. (2016). Omnishopper 2016: Taking the Long-Term View on Keeping the Customer. https:/insights.mastercard.com/omnishopper/assets/downloads/MasterCardOmnishopperKeyFindingsRepor t.pdf

McKinsey. (2016). More than digital plus traditional: A truly omnichannel customer experience http://www.mckinsey.com/business-functions/operations/our-insights/more-than-digital-plustraditional-atruly-omnichannel-customer

Midgley, D. F. and Dowling, G. R. (1978). Innovativeness: The concept and its measurement. Journal of Consumer Research, 229-242.

Moore G. C., Benbasat I. (1991). Development of an instrument to measure the perceptions of adopting an information technology innovation. Inf. Syst. Res. 2, 192-222. 10.1287/isre.2.3.192

NRF, 2016. OMNICHANNEL RETAIL INDEX: 2015 HOLIDAY FINDINGS,

Nunnally, J. C. (1978). Psychometric theory (2nd ed.). New York, NY: McGraw-Hill.

Nunnally, J. C., \& Bernstein, I. H. (1994) Psychometric theory (3rd ed.). New York, NY: McGraw-Hill, Inc.

Oh, L., Teo, H. \& Sambamurthy, V., (2012). The effects of retail channel integration through the use of information technologies on firm performance. Journal of Operations Management, 30(5), 368-381.

Ouellette, J. A., \& Wood, W. (1998). Habit and intention in everyday life: The multiple processes by which past behavior predicts future behavior. Psychological bulletin, 124(1), 54.

Pappas, I. O., Kourouthanassis, P. E., Giannakos, M. N., \& Chrissikopoulos, V. (2014). Shiny happy people buying: the role of emotions on personalized e-shopping. Electronic Markets, 24(3), 193-206.

Pantano, E., \& Di Pietro, L. (2012). Understanding consumer's acceptance of technology-based innovations in retailing. Journal of technology management \& innovation, 7(4), 1-19.

Pantano, E., \& Viassone, M. (2015). Engaging consumers on new integrated multichannel retail settings: Challenges for retailers. Journal of Retailing and Consumer Services, 25, 106-114.

Pascual-Miguel, F. J., Agudo-Peregrina, Á. F., \& Chaparro-Peláez, J. (2015). Influences of gender and product type on online purchasing. J. Bus. Res. 68, 1550-1556.

Picot-Coupey, C., Huré, E., Piveteau, L., forthcoming. Channel design to enrich consumers' shopping experiences: 
synchronizing clicks with bricks in an omni-channel perspective - the Direct Optic case. International Journal of Retail \& Distribution Management.

Piotrowicz, W., \& Cuthbertson, R. (2014). Introduction to the special issue information technology in retail: Toward omnichannel retailing. International Journal of Electronic Commerce, 18(4), 5-16.

Preacher, K. J., \& MacCallum, R. C. (2002). Exploratory factor analysis in behavior genetics research: Factor Recovery with small sample sizes. Behavior Genetics, 32, 153-161.

Rigby, D. (2011). The future of shopping: successful companies will engage consumers through "omnichannel" retailing: a mashup of digital and physical experiences. Harvard Business Review, 89(12), 65-74.

Rogers, E. M. (2010). Diffusion of innovations. Simon and Schuster.

Rose S., Clark M., Samouel P., Hair N. (2012). Online customer experience in e-retailing: an empirical model of antecedents and outcomes. J. Retail. 88, 308-322. 10.1016/j.jretai.2012.03.001

San Martín, H., \& Herrero, Á. (2012). Influence of the user's psychological factors on the online purchase intention in rural tourism: Integrating innovativeness to the UTAUT framework. Tourism Management, 33(2), 341350.

Santos, J. A. R. (1999). Cronbach's Alpha: A Tool for Assessing the Reliability of Scales. Journal of Extension, $37,1-5$

Salisbury, W. D., Pearson, R. A., Pearson, A. W., and Miller, D. W. (2001). Perceived security and world wide web purchase intention. Ind. Manag. Data Syst. 101, 165-176.

Schifter D. E., Ajzen I. (1985). Intention, perceived control, and weight loss: an application of the theory of planned behavior. J. Pers. Soc. Psychol. 49, 843-851. 10.1037/0022-3514.49.3.843

Slade, E. L., Williams, M. D. and Dwivedi, Y. K. (2014) Devising a research model to examine adoption of mobile payments: An extension of UTAUT2. The Marketing Review, 14(3), 310-335.

Teece, D.J (2010). Business models, business strategy and innovation, Long Range Planning, 43(2-3), $172-194$.

Tetteh, and Xu, (2015). Supply Chain Distribution Networks: Single-, Dual-, \& Omni-Channel. International Journal of Production Economics, 165, pp.100-111.

Thong J. Y. L., Hong S. J., Tam K. Y. (2006). The effects of post-adoption beliefs on the expectation-confirmation model for information technology continuance. Int. J. Hum. Comp. Stud. 64, 799-810. 10.1016/j.ijhcs.2006.05.001

Venkatesh, V., \& Davis, F. D. (2000). A theoretical extension of the technology acceptance model: Four longitudinal field studies. Management science, 46(2), 186-204.

Venkatesh, V., Morris, M., Davis, G. and Davis, F. (2003) User acceptance of information technology: Toward a unified view. MIS Quarterly, 27(3), 425-478.

Venkatesh, V., \& Bala, H. (2008). Technology acceptance model 3 and a research agenda on interventions. Decision sciences, 39(2), 273-315.

Venkatesh, V., Thong, J. \& Xu, X. (2012) Consumer acceptance and use of information technology: extending the unified theory of acceptance and use of technology. MIS Quarterly, 36(1), 157-178.

Verhoef, P. C., Kannan, P. K., \& Inman, J. J. (2015). From multi-channel retailing to omni-channel retailing: introduction to the special issue on multi-channel retailing. Journal of retailing, 91(2), 174-181.

Woodruff RB. Consumer value: the next source for competitive advantage. J Acad Mark Sci 1997, 53, Spring.

Xu, H. \& Gupta, S. (2009). The effects of privacy concerns and personal innovativeness on potential and experienced customes' adoption of location-based services. Electronic markets: Routledge. 19(2-3), 127-149.

Yenisey, M. M., A.A. Ozok, \& G. Salvendy. (2005). Perceived Security Determinants in E-commerce among Turkish University Students. Behaviour and Information Technology, 259-274.

\section{APPENDIX}

This section will contain all the questions from the survey, the parameters of the observation and the questions from the interviews.

\section{APPENDIX 1 - FIELD RESEARCH OMNICHANNEL PARAMETERS}

These parameters were selected asses the current omnichannel development in the field study

\section{Fulfillment}

\section{Availability in-store}

Product availability in store is noted on web page

Product availability in store is noted on web page in real time (no "unsure", "contact store").

Sort - In-store availability.

On a mobile device ability to look up in availability in store

On a mobile device ability to look up in product availability in store to closest to you. 


\section{Delivery \& Returns}

Buy online pick up in store (BOPIS / Click \& Collect)

Are there any incentives when buying online and pick up in store? Example free shipment BOPIS (C\&C) from mobile site.

Buy online reserve in store

Multi-ship options

Free Shipping

Buy Online Return in Store (BORIS)

Free Return Shipping

\section{Channel Synchronization}

Same price online \& offline

Do you use the same offers online and offline?

Shopping cart transfers between devices

Does every B\&M store have their own space on your website?

Is there a map with directions online to your closest B\&M store? GPS

Is it possible to write a shopping list online and then bring to your B\&M stores?

Cross-Channel gift card/coupon usage (ask)

Site is mobile optimized

Is there a mobile application that you can purchase from?

In-storage signage about Omnichannel Service

WIFI- available in store

Access to information about products from B\&M by mobile? QR codes for online reviews. It's possible to order from online assortment from store with in the store?

\section{Loyalty}

Email sign-up incentive (Online)

Does your customers receive loyalty points when purchasing both online and in B\&M?

Can your customers use their loyalty points when shopping online?

Can your customers see their loyalty points online?

Can you see loyalty points in mobile optimized store?

In-store sign up for loyalty program.

\section{Frictionless Online Experience}

Search - Autocomplete (with pictures)

Sort - Faceted Navigation

Sort - Faceted Navigation Reviews

Stickers such as "Exclusive", "web only" and "best seller"

Customer Ratings

Product Upsell

Edit attributes in cart (Size + Color + Quantity)

Product Shipping Status

Threshold messaging

Total Cost Breakdown Cart

Edit product attributes Checkout (at least 2 factors)

Optional account creation

Save for later (Automatic cart save)

\section{Customer Service}

Customer service link in page header

Customer Service option on Product Page

Customer service options noted in checkout

Email (Customer service)

Phone (Customer service)

Live Chat (Customer service)

FAQ (Customer service)

User generated Q\&A (Customer service)

Mobile site click to call (customer service) available 
APPENDIX 2 - SURVEY QUESTIONS RETAILERS

The following questions was used in the digital survey

\section{Business Transformation}

Q1) Our organization is fully committed to delivering an omnichannel retail experience to our customers?

1) Strongly disagree 2) Disagree 3) Neither agree nor disagree 4) Agree 5) Strongly agree

Q2) When did you start working towards an Omnichannel experience for your customers?

1) Haven't started working yet and haven't planned

2) Haven't started working yet but are planning

3) < 1 year ago

4) 1-3 years ago

5) 3-5 Years ago

6) $>5$ years ago

Q3) Omnichannel retailing requires a substantial re-engineering of your business operations and strategy?

1) Strongly disagree 2) Disagree 3) Neither agree nor disagree 4) Agree 5) Strongly agree

Q4) Omnichannel retailing requires a transformation of front-end operations in order to deliver a seamless experience to your customers?

1) Strongly disagree 2) Disagree 3) Neither agree nor disagree 4) Agree 5) Strongly agree

Q5) Omnichannel retailing requires a transformation of back-end operations to deliver a seamless experience to customers?

1) Strongly disagree 2) Disagree 3) Neither agree nor disagree 4) Agree 5) Strongly agree

Q6) We have an agile organization that can easily transform to deliver an Omnichannel experience?

1) Strongly disagree 2) Disagree 3) Neither agree nor disagree 4) Agree 5) Strongly agree

Q7) Have you changed, modified or added any of the following systems in order to deliver better omnichannel experience to your customers?

1) OMS (Order Management System)

2) CRM (Customer Relationship System)

3) E-commerce platform

4) CMS (Content Management System)

5) Mobile application / optimization

6) PIM (product information management)

7) ERP (Enterprise Resource Planning)

8) POS (Point of Sale)

9) Warehouse and in-store logistic management

10) Business Intelligence Payment systems

11) Other

Q8) We are planning several changes, modifications or additions in our IT environment to deliver a better Omnichannel experience

1) Strongly disagree 2) Disagree 3) Neither agree nor disagree 4) Agree 5) Strongly agree

Q9) Transforming your business in order to create an Omnichannel experience for your customers is associated with a great risk?

1) Strongly disagree 2) Disagree 3) Neither agree nor disagree 4) Agree 5) Strongly agree

Q10) What would you consider as the greatest risks with an Omnichannel transformation?

1) Integration of channels leads to cannibalization of sales

2) Increased operational costs Up-front capital investments / Cash flow

3) Development of a viable omnichannel strategy

4) Uncertainties in the transformation process

5) No financial benefits

6) Manage change of internal organization

7) Lack of digital maturity in internal organization 
8) Other

\section{Omnichannel Organization}

Q11) Who is in charge of driving a unified retail experience across all channels?
1) Leadership Team
2) CIO, CTO, or similar
3) IT department
4) Each department is responsible their own channel
5) No one
6) Other

Q12) In our organization each channel operates independently and have autonomous business goals?

1) Strongly disagree 2) Disagree 3) Neither agree nor disagree 4) Agree 5) Strongly agree

Q13) We have created a position (Chief Digital Officer or similar) with the responsibility for driving our Omnichannel experience across all channels.

1) Strongly disagree 2) Disagree 3) Neither agree nor disagree 4) Agree 5) Strongly agree

\section{Data and Analytics}

Q14) Data and analytics are of great importance for our organization's business?

1) Strongly disagree 2) Disagree 3) Neither agree nor disagree 4) Agree 5) Strongly agree

Q15) We have the technical systems/software needed to extract all the relevant customer data we need?

1) Strongly disagree 2) Disagree 3) Neither agree nor disagree 4) Agree 5) Strongly agree

Q16) We have the analytical capabilities needed in order to gain the insights we want from our data?

1) Strongly disagree 2) Disagree 3) Neither agree nor disagree 4) Agree 5) Strongly agree

Q17) What would you consider as the most important areas for your organization to improve within data and analytics?

1) Inventory forecasting \& replenishment

2) Personalization of ecommerce site

3) Understanding customer behaviors

4) Digitalizing physical store

5) Targeted promotions and offerings

6) Data driven business decisions

7) More accurate KPI's and measurements

8) Other

Q18) we currently measure cross channel sales?

1) Strongly disagree 2) Disagree 3) Neither agree nor disagree 4) Agree 5) Strongly agree

Q19) Our sales associates/managers are rewarded for cross channels sales?

1) Strongly disagree 2) Disagree 3) Neither agree nor disagree 4) Agree 5) Strongly agree 